\title{
LA EXCEPCIÓN DE CONTRATO NO CUMPLIDO, UN ANÁLISIS DE SU APLICACIÓN EN LA JURISPRUDENCIA NACIONAL RECIENTE Y EN LA DOCTRINA*
}

\section{Claudia Mejías Alonzo**}

RESUMEN: En este trabajo nos centraremos en un análisis crítico de tres aspectos vinculados a la procedencia y aplicación de la excepción de contrato no cumplido: la exigibilidad de las obligaciones bilaterales y, dentro de este tópico, la posibilidad de oponer, con alcance general, la excepción de contrato no cumplido en casos de incumplimiento previsibles; el incumplimiento que hace procedente la exceptio, lo que necesariamente implica tomar partido acerca de la necesidad de gravedad del mismo para que pueda prosperar y, finalmente, la prueba de la excepción de contrato no cumplido. Tangencialmente, además, precisaremos algunos aspectos vinculados a sus efectos. Para esto nos centraremos principalmente en la jurisprudencia nacional, para sentar criterios y/o proponer, lo que nos parece, una adecuada interpretación a partir de los problemas que se suscitan, de cara al fundamento y naturaleza de esta institución y acudiremos, de forma complementaria, a la doctrina nacional y comparada.

PALABRAS CLAVE: Excepción de contrato no cumplido - incumplimiento contractual - gravedad del incumplimiento - exigibilidad de las obligaciones bilaterales.

\section{EXCEPTIO NON ADIMPLETI CONTRACTUS. AN ANALYSIS OF ITS APPLICATION IN RECENT NATIONAL JURISPRUDENCE AND DOCTRINE}

ABSTRACT: This paper centers on a critical analysis of three aspects related to the origin and application of exceptio non adimpleti contractus:

\footnotetext{
El presente artículo es resultado de la ejecución del Proyecto Fondecyt de Iniciación Nro.11110208, financiado por Fondecyt.

Fecha de recepción: 11 de septiembre de 2013.

Fecha de aceptación: 16 de marzo de 2014.

** Doctora en Derecho, Escuela de Derecho, Pontificia Universidad Católica de Valparaíso. Profesora de Derecho civil e Introducción al Estudio del Derecho, Escuela de Derecho, Pontificia Universidad Católica de Valparaíso. Correo electrónico: claudia.mejias@ucv.cl
} 
first, the enforceability of bilateral obligations and, within it, the possibility of opposing, with general reach, exceptions of non-performance in cases of foreseeable breaches; next, breaches that give origin to the exceptio, which necessarily imply taking sides regarding the need for establishing the severity of the breach, so that legal actions may succeed; and, finally, the proof for exceptions of non-performance. Furthermore, and as a tangent to the above, the paper will discuss some effect-related aspects. To accomplish this, the discussion will mainly focus on national jurisprudence in order to establish criteria and/or propose an adequate interpretation based on problems that have arisen. In addition, the paper will face the foundations and nature of this institution and will complementarily approach national and compared doctrine.

KEY WORDS: Exception of non-performance - breach of contract severity of breach - enforceability of bilateral obligations.

Sumario: Introducción. 1) La exigibilidad de las obligaciones emanadas de un contrato bilateral. 2) El incumplimiento y su gravedad. 2.1.) Fundamento de la exigencia de gravedad del incumplimiento. 2.2) La gravedad del incumplimiento en la jurisprudencia nacional. 2.2.1) La proporcionalidad del incumplimiento. 2.2.2) Causalidad del incumplimiento. 2.2.3) El incumplimiento y la conducta del deudor que lo acepta. 3) La prueba de la excepción de contrato no cumplido. Conclusiones. Bibliografía.

\section{INTRODUCCIÓN}

La excepción de contrato no cumplido es un mecanismo de defensa del deudor que encuentra su fundamento en el principio de ejecución simultánea de las obligaciones que emanan de un contrato bilateral, que le permite, no obstante haber incumplido con su obligación, suspender el cumplimiento mientras el acreedor no cumpla o se allane a hacerlo. Conforme a lo anterior creemos, como suele afirmarlo la mayoría de la doctrina, que la excepción de contrato no cumplido es un mecanismo de defensa del deudor, una excepción de derecho sustantivo; descartamos que se trate de un requisito de la acción de cumplimiento ${ }^{1}$.

1 Por todos véase Espín Cánovas, Diego (1964)."La excepción de incumplimiento contractual”. Anuario de Derecho civil (Madrid), Nro. 17, vol. 2, p. 550. No obstante ser esta la opinión mayoritaria en nuestra doctrina, es posible encontrar fallos en los que expresamente se declara que la excepción de contrato no cumplido es un requisito de la acción de cumplimiento, con la consecuencia lógica en el ámbito probatorio: será el acreedor quien deberá 
En el presente trabajo pretendemos centrarnos en algunos de los requisitos que determinan la procedencia de la excepción de contrato no cumplido. Con relación a ellos, la doctrina suele mencionar: que estemos en presencia de un contrato bilateral; que las obligaciones sean actualmente exigibles; que el acreedor, contra quien se opone la excepción, no haya cumplido con su prestación ni se encuentre llano a hacerlo y, se agrega, por la mayoría de los autores, que el deudor la oponga de buena $\mathrm{fe}^{2}$.

En concreto abordaremos dos de estos requisitos, porque han originado un interesante debate doctrinal, lo que tiene directa incidencia en su aplicación: la exigibilidad de las obligaciones emanadas de un contrato bilateral y la gravedad del incumplimiento. Nuestra finalidad es proponer criterios que faciliten el empleo de esta institución a partir del cotejo y contraste de las soluciones jurisprudenciales ${ }^{3}$ y doctrinales. A continuación nos referiremos a la prueba de la excepción de contrato no cumplido, temática fundamental para que pueda prosperar su interposición y que se relaciona con el requisito de que el acreedor no haya cumplido con su obligación ni se encuentre llano a hacerlo. Finalizaremos este artículo con un cuerpo de conclusiones.

\section{1) LA EXIGIBILIDAd DE LAS OBLIGACIONES EMANADAS DE UN CONTRATO BILATERAL}

La exigibilidad de las obligaciones emanadas de un contrato bilateral se nos presenta, en la doctrina nacional, como un requisito evidente para

probar que ha cumplido con su obligación o que se encontraba llano a hacerlo, sobre este punto volveremos más adelante en este artículo.

Acerca de la naturaleza y fundamento de la excepción puede consultarse De LA Prida, Manuel (2012). La excepción de contrato no cumplido: Fundamento y naturaleza jurídica. Tesis para optar al grado de Licenciado en Ciencias Jurídicas. Valparaíso, 117 pp. Mejías Alonzo, Claudia (2013). "La excepción de contrato no cumplido y su consagración en el Código civil chileno". Revista Chilena de Derecho, vol. 40 No 2, pp. 389-412.

2 AвеLIUk, René (2010). Las obligaciones. Tomo II. 5a Edición. Santiago: Editorial Jurídica de Chile, pp. 943-945. La jurisprudencia suele hacer eco de estos requisitos. Se aleja de esta tendencia la sentencia de la Corte Suprema, que indica como requisitos: "a) la existencia de un contrato, b) que este sea bilateral, c) que las obligaciones recíprocas que de él emanen deban cumplirse simultáneamente, d) que esas tengan un contenido patrimonial; e) que el contratante contra quien se opone no haya cumplido o no se allanare a cumplir; y f) que tal incumplimiento revista cierta entidad". Corte Suprema. 7 de marzo de 2012. Rol No 3946-2011. "Irina Buvinic Gonella con Complejo Turístico Marbella S.A". Disponible en http://www.legalpublishing3.cl/maf/app/documentVM?\&src=laley\&lr=i0ad600790000014 08916d145b114dfd8\&docguid=i0ADFAB87B571733981B5732BBE34E200\&hitguid $=\mathrm{i} 0$ ADFAB87B571733981 B5732BBE34E200\&epos $=1 \& \mathrm{td}=1 \& \mathrm{ao}=\mathrm{o} . \mathrm{i} 0 \mathrm{ADFAB} 87 \mathrm{~B} 0 \mathrm{C} 8 \mathrm{D} 2538$ 1B0D0F03ED6FB4C\&searchFrom=\&savedSearch=false\&crumb-action=append [fecha de visita 16 de agosto de 2013].

3 Precisamos que para efectos de este artículo hemos considerado la jurisprudencia nacional entre los ańos 2000 a 2013. 
que pueda prosperar la excepción de contrato no cumplido, de allí que se sostenga que es necesario que la obligación sea pura y simple o bien que, tratándose de una obligación a plazo, este se encuentre vencido, con independencia de que el crédito sea líquido o no ${ }^{4}$. En la misma dirección se ha pronunciado nuestra Corte Suprema negando la procedencia de la excepción, en casos en que ha existido una prórroga del plazo y este aún no se ha cumplido, así ha afirmado: "Que, como directa consecuencia de lo anterior, resulta forzoso declarar la impertinencia de la prueba testimonial producida por la demandada para demostrar un supuesto incumplimiento contractual de la actora puesto que los deponentes ignoran o no consideran que fue la propia demandada la que con antelación prorrogó el término para hacer exigible las obligaciones del promitente vendedor, lo que permite concluir que la demandante se encuentra en aquella situación que previó el artículo 1552 del Código Civil, por cuanto, a diferencia de su contratante, no ha incurrido en el incumplimiento de las obligaciones asumidas en el contrato de promesa de compraventa, desde que las mismas, por una determinación de su contraparte, no le eran exigibles al 30 de octubre de 2007"'.

4 En la doctrina nacional, por todos Abeliuk (2010), p. 945. López Santa María, Jorge (2010). Los contratos: Parte General. 5a edición. Santiago: Editorial Jurídica de Chile, pp. 497-498. En la doctrina española, Espín (1964), p. 562. Rodríguez-Rosado, Bruno (2013). Resolución y sinalagma contractual. Madrid: Editorial Marcial Pons, pp. 101-102. En la doctrina francesa, por todos CAssin, René (1914). De l'exception tirée de l'inexécution dans les rapports synallagmatiques: exception non adimpleti contractus. Paris: Librairie de la Société du Recueil Sirey, pp. 503 y ss. Malecki, Catherine (1999). L'exception d'inexécution. Paris: L.G.D.J., p. 256. Ghestin, Jacques (2001). “Exception d' Inexécution”. En Fontaine, Marcel; Viney, Geneviève (coordinadores): Les sanctions de l'inexécution des obligations contractuelles. Bruselas: L.G.D.J., pp. 39-40.

Alcalde pretende plantear, entre nosotros, contornos más amplios a la exigibilidad como una cualidad de la relación jurídica obligatoria que hace actual tanto el deber de prestación como la facultad del acreedor de exigir la satisfacción del interés que perseguía al momento de contratar, no centrado solo en la facultad del acreedor. Ello nos parece está implícito en lo sostenido por la mayoría de la doctrina nacional. Alcalde Silva, Jaime (2011). "El tratamiento de los incumplimientos recíprocos en el derecho chileno". En Carvajal, Patricio; Miglietta, Massimo (a cura di): Estudios Jurídicos en homenaje al profesor Alejandro Guzmán Brito. Milán: Edizioni dell'Orso, pp. 43-45. En sentido similar previamente aludiendo a la exigibilidad del crédito y la exigibilidad de la prestación, debiendo ambos entrecruzarse para que la obligación sea realmente exigible. BARAOnA, Jorge (2008). "Algunas consideraciones sobre el retraso en el cumplimiento de las obligaciones: su configuración y eficacia”. En Pizarro, Carlos (coordinador): Estudios de Derecho civil V. Santiago; Editorial LegalPublishing, pp. 370 y ss.

5 Corte Suprema. 25 de mayo de 2012. Rol No 12046-2011. "Eduardo Esteban Maraldi Olivo con Inmobiliaria Cores S.A.”. Disponible en http://www.legalpublishing3.cl/maf/ app/documentVM? \&src=laley\&lr=i0ad60079000001409757db991d14e033\&docguid=i0A DFAB87B706F0A881B71582079AF8F3\&hitguid=i0ADFAB87B706F0A881B71582079A $\mathrm{F} 8 \mathrm{~F} 3 \&$ epos $=1 \& \mathrm{td}=1 \& \mathrm{xao}=\mathrm{o} . \mathrm{i0ADFAB} 87 \mathrm{~B} 0 \mathrm{C} 8 \mathrm{D} 25381 \mathrm{~B} 0 \mathrm{D} 0 \mathrm{~F} 03 \mathrm{ED} 6 \mathrm{FB} 4 \mathrm{C} \&$ searchFrom $=$ \&savedSearch=false\&crumb-action=append [fecha de visita 19 de agosto de 2007], considerando décimo tercero.

Se demandó el cumplimiento forzado de un contrato de promesa de compraventa de un departamento y pago de la pena convenida. La demandada opuso la excepción de contrato 
Tratándose de la exigibilidad es necesario considerar que parte de la doctrina nacional ha sostenido que en los contratos bilaterales, atendido a que ambas obligaciones deben cumplirse simultáneamente, la simultaneidad se convertiría en un requisito de exigibilidad de las obligaciones ${ }^{6}$. Con relación a esto, nos parece necesario precisar que el campo propio de aplicación de la excepción de contrato no cumplido dice relación con aquellos contratos bilaterales cuyas obligaciones deben ser cumplidas simultáneamente, es más, ya habíamos anticipado que el principio de ejecución simultánea de esta clase de obligaciones es el fundamento mismo de la institución. Lo anterior va ligado necesariamente a los efectos que la exceptio despliega, una vez que se ha verificado el incumplimiento, como lo entiende la doctrina que afirma la simultaneidad como presupuesto de exigibilidad de las obligaciones bilaterales; de allí entonces que si el acreedor no ha cumplido con su prestación ni si encuentra llano a hacerlo no puede pretender que su deudor cumpla, pudiendo este, por ende, oponerse mediante la excepción de contrato no cumplido.

No compartimos que en estos supuestos se afecte la exigibilidad de las obligaciones bilaterales si ninguno de los contratantes ha cumplido o se encuentra llano a hacerlo y con ello el presupuesto para que opere la excepción de contrato no cumplido y, en general, cualquier remedio del acreedor que presuponga la exigibilidad de la prestación. Distinguimos de esta forma, los requisitos para que opere la excepción de contrato no cumplido -aquí situamos la exigibilidad de las obligaciones-, de los posibles efectos que pueda tener la excepción de contrato no cumplido y en ello, a su vez, tiene relevancia en rigor solo los requisitos propios de cada remedio ${ }^{7}$. La exigibilidad dependerá, en términos generales, de que la prestación no esté sujeta a modalidades, mas no con que se dé cumplimiento a la ejecución simultánea, de lo contrario la excepción de contrato

no cumplido, argumentado que ha sido la desidia y mora de la otra parte la que no le ha permitido cumplir. La Corte entiende que en este caso operó una prórroga del plazo fijado en el contrato de promesa, en su cláusula cuarta, antes de su vencimiento, por parte de la inmobiliaria atendido el retraso en la recepción definitiva del inmueble, lo que fue aceptado tácitamente, al menos, por la actora. El nuevo plazo condujo a la inexigibilidad de la prestación de la actora que la deudora consideró incumplida.

6 Baraona (1998), pp. 380-384. El autor afirma que si el deudor no cumple ni se encuentra llano a hacerlo, al momento que la contraparte cumpla, la contraparte no queda en mora en caso que le hubiere llegado el tiempo de cumplir. Afirma que entonces, no hay mora porque no hay verdadero incumplimiento y esto es porque la obligación correlativa no es verdaderamente exigible.

7 En esta oportunidad, como adelantáramos, no nos centremos en rigor en los efectos que produce la excepción de contrato no cumplido, sí precisamos que parte de la doctrina afirma que ella conlleva a la inexigibilidad de la prestación, en este sentido Fernández URZAINQUi, Francisco (1997). "la regla de la simultaneidad en el cumplimiento de las obligaciones bilaterales". Revista Critica de Derecho Inmobiliario, Nro. 639, pp. 403-462. Baraona (1998), pp. 380-384. 
no cumplido no operaría en su supuesto propio y se atentaría con el fundamento y finalidad de la institución ${ }^{8}$.

Vinculado a este requisito, cabe tener presente que existe consenso en la doctrina en orden a afirmar la procedencia de la excepción de contrato no cumplido en los contratos bilaterales cuyas obligaciones no son de cumplimiento simultáneo; las que a nuestro juicio son las que mayormente se darán en el tráfico jurídico. En esos casos, la parte que debe cumplir anticipadamente ve afectada la exigibilidad de la prestación de la contraparte mientras no realice la prestación de lo que debe, ya sea porque así lo han acordado las partes, o porque proviene de un mandato legal o de la propia naturaleza del contrato. Consecuentemente solo podrá oponer con éxito la excepción de contrato no cumplido el otro contratante, aquel que no ha debido cumplir primero 9 .

Menos abordado entre nosotros ha sido la posibilidad de oponer la excepción de contrato no cumplido en casos de incumplimiento anticipado, lo que en doctrina se suele denominar excepción preventiva de incumplimiento contractual ${ }^{10}$. Se alude a un incumplimiento anticipado

8 A la misma conclusión aunque no compartimos todas su premisas, entre otras razones porque superpone ámbitos que nos parecen distintos, los presupuestos versus efectos de la institución. AlCalde (2011), pp. 48-64.

9 Espín (1964), p. 583. Claro Solar, Luis (1978). Derecho civil chileno y comparado, Tomo $X$ : De las Obligaciones. Santiago: Editorial Jurídica de Chile, pp. 788-789. En la misma dirección se han pronunciado nuestros tribunales, Corte de Apelaciones de Copiapó. 12 de mayo de 2008. Rol No 8-2008. "Inmob. Xcaret Ltda. Con Inmob. Einers. Ramón Sánchez y Cía. Ltda.”. Disponible en http://vlex.com/vid/inmob-xcaret-iners-ramon-sanchez38318190 ? ix_resultado $=1.0 \&$ query $\% 5 \mathrm{~Bq} \% 5 \mathrm{D}=38318190$ [fecha de visita 19 de agosto de 2013], considerando séptimo. En la doctrina comparada, Rodríguez-Rosado (2013), p. 104, Malecki (1999), p. 257. Cruz Moreno, María (2004). La Exceptio non Adimpleti Contractus. Madrid:Tirant lo Blanch, p. 72. Ghestin (2001), p. 40.

Precisamos que en la doctrina italiana se enuncia una regla similar pero se prevén excepciones que se vinculan con la denominada excepción preventiva de incumplimiento contractual: si la otra parte previamente declara su voluntad de no querer cumplir o si resulta cierta y fundada la probabilidad de que no cumplirá. Bigliazzi, Lina (1988). "Risoluzione per inadempimento". En Galgano, Francesco (a cura di): Commentario del Codice civile ScialojaBranca. Bologna: Nicola Zanichelli Editore, p. 24. Realmonte, Francesco (1965). Voz "Eccezione di inadempimento". Enciclopedia del Diritto, vol XV, pp. 228-229.

10 Abeliuk (2010), pp. 948-949; de la misma forma lo hace Galván Bernabeu, José Antonio (1998). "Conferencia Inaugural del II Congreso Chileno de Derecho Privado". Revista de Derecho de la Universidad Católica de Valparaíso, vol. XIX, pp. 13 y ss. En la doctrina comparada, se le ha denominado también excepción anticipatoria, así lo hace, por ejemplo, CARrasco Perera, Ángel (2010). Derecho de Contratos. Madrid: Ed. Thomson Reuters, p. 1055.

Alcalde Silva, siguiendo a Puig Peńa, alude a incumplimiento intentado para referirse a los casos en los que existe la probabilidad de que la insatisfacción del interés del acreedor llegue a ser cierta en un futuro más o menos inmediato. Señala que ante ellos el ordenamiento jurídico reacciona a través de la pérdida de beneficios del deudor, tales como: la caducidad del plazo (art. 1496 del CC.), el cumplimiento ficto de la obligación (art. 1481 del CC.), los efectos de la pérdida de la cosa debida por culpa del deudor pendiente la condición suspensiva (art.1486 del CC.), la pérdida de la facultad del deudor de administrar sus bienes debido a medidas conservativas y la excepción de incumplimiento preventivo que entiende 
porque este aún no se ha verificado. Las prestaciones no deben ser ejecutadas aún porque su exigibilidad está supeditada al cumplimiento de una modalidad. Sin embargo, atendidas las circunstancias y antecedentes que se disponen resulta razonablemente presumible que se producirá el incumplimiento. En este supuesto, adicionalmente, confluyen los efectos de la institución, pudiendo incluso considerarse su ejercicio como una forma de resolución unilateral ${ }^{11}$. En esta ocasión nos centraremos simplemente en lo primero, la procedencia de la excepción en casos de incumplimiento anticipado o previsible.

En la doctrina nacional, la postura mayoritaria se inclina por rechazar la admisibilidad de una excepción preventiva, toda vez que se considera que la obligación del demandante contra quien se opone la excepción no es actualmente exigible. En esta línea el profesor Abeliuk afirma que el acreedor solo puede asilarse en la excepción de contrato no cumplido cuando tiene derecho a exigir el crédito, "de manera que si la obligación del deudor cuyo incumplimiento fundado se teme no es exigible, no puede el acreedor negar su propio cumplimiento si él es exigible" 12 .

con eficacia limitada a partir del tenor del art. 1826 del CC. y más amplia en la compraventa internacional de mercaderías a partir del artículo 72 CISG.; más adelante, vincula el incumplimiento anticipado directamente con la resolución más no con la procedencia de la excepción de contrato no cumplido. Alcalde (2011), pp. 46-48, pp. 62-63.

La noción de incumplimiento anticipado es propia del derecho anglosajón, noción que en rigor se relaciona con la terminación del contrato, sobre la particular, véase Zweigert, Konrad; Kötz, Heim (1998). Introduction to comparative law, 2a Edition. New York: Clarendon Press Oxford University, pp. 508 y ss. AтіYAн, P.S; Sмiтh, Stephen (2005). Atiyah's Introduction to the law of contract. $6^{\mathrm{a}}$ Edition. New York: Clarendon Press Oxford University, pp. 201 y ss. Treitel, Guenter (2004). An outline of the law of contract. 6a Edition. New York: Clarendon Press Oxford University, pp. 346-349. En la doctrina francesa Pinna diferencia la excepción por riesgo de incumplimiento del incumplimiento anticipado, en el primer caso el incumplimiento de una obligación sujeta a plazo es simplemente probable, mientras que en el segundo, es cierto. Pinna, Andrea (2003). "L'exception pour risque d'inexécution". Revue trimestrielle de droit civil, pp. 33 y ss.

11 Sobre el particular puede verse Malecki (1999), pp. 103-137. En nuestra doctrina Pizarro plantea que puede constituirse en un mecanismo de justicia privada que opera ajeno a los tribunales de justicia. Pizarro Wilson, Carlos (2011). "La excepción por incumplimiento contractual en el derecho civil chileno”. En Varas Braun, Juan Andrés; Turner Saelzer, Susan y otros (coordinadores): Estudios de Derecho Civil. Jornadas nacionales de derecho civil 20052009. Tomo II, Santiago: Abeledo Perrot, pp. 181 y ss.

En la doctrina francesa, Pinna plantea las ventajas de la suspensión de la prestación en comparación con la resolución en estas hipótesis, así como la evolución en el derecho francés en la aceptación de la excepción por riesgo de incumplimiento, coherente con el nuevo derecho de contratos. En definitiva postula que la confianza es un elemento esencial del contrato a plazo y es precisamente la desaparición legítima de la confianza lo que conlleva a la desaparición del plazo convenido, permitiendo al deudor de la obligación previa suspender el cumplimiento de sus obligaciones. Pinna (2003), pp. 31 y ss.

12 Abeliuk (2010), p. 949. El autor agrega que no existe en el Código otra institución que permita al acreedor en estos casos negar el cumplimiento, siendo únicamente a favor del comprador en la compraventa, hace referencia al artículo 1826. Norma que califica de excepcional lo que impediría extenderla a otras hipótesis. 
Algunos autores agregan, además, que operaría otra institución prevista en nuestro ordenamiento jurídico, la caducidad del plazo. En esta última postura encontramos al profesor Bruno Caprile quien sostiene que debe distinguirse si en estos casos ha operado o no la caducidad del plazo, sea de origen legal (artículo 1496 del CC.) o convencional. En caso afirmativo, la obligación se hará inmediatamente exigible habilitando al excipiens para oponer la excepción. A falta de causal que produzca la caducidad del plazo, reconoce que el legislador prevé manifestaciones de esta excepción en casos específicos, materia de compraventa, artículos 1826 y $1872^{13}$, mas el autor no se refiere categóricamente a un posible alcance general de estas disposiciones.

En nuestro ordenamiento jurídico, al igual que en el derecho francés, no contamos dentro del Código civil con una norma que la prevea expresamente en términos generales, como acontece en otros sistema jurídicos ${ }^{14}$. Como adelantáramos tres son las disposiciones que la doctrina

Por su parte Luis Claro Solar califica la facultad del artículo 1826 como un derecho legal de retención, Claro Solar (1978), pp. 575-576.

13 Caprile Biermann, Bruno (2012). "Algunos problemas ofrecidos por la excepción de contrato no cumplido y, en especial, el de su invocación para atajar la acción resolutoria en el caso de incumplimiento recíproco de los contratantes". Revista de Derecho de la Pontificia Universidad Católica de Valparaíso. Nro. 39. Disponible en: http://www.scielo.cl/scielo. php?pid=S0718-68512012000200002\&script=sci_arttext [fecha de visita 19 de agosto de 2013]. El autor agrega: "La denominada excepción de contrato no cumplido por anticipación puede ayudarnos a avanzar en la comprensión de las reglas citadas del Código Civil y, quizá, a dar sustento dogmático para quienes pretendan extender su aplicación a otros casos distintos de los expresamente regulados en el Código de Bello".

14 Es el caso del artículo 1461 del Código Civil italiano. Sobre el particular la doctrina afirma que no existe plena coincidencia con la excepción de contrato no cumplido, pues ella requiere de un incumplimiento actual y efectivo, mientras que la disposición en comento supone un incumplimiento futuro e incierto, y que los términos de cumplimiento son distintos, habilitándose al obligado a cumplir primero para suspender la ejecución. Persico, Giovanni (1955). Eccezione d'inadempimento. Milano: Giuffré, p. 85. Diferenciado los supuestos Bigliazzi hace presente que en ambos casos existe un peligro para la situación del acreedor mas el artículo 1461 atribuye relevancia no a un comportamiento, el incumplimiento, sino a un dato fáctico: el detrimento de las condiciones patrimoniales, es decir, concerniente a la esfera económica del otro contratante. Bigliazzi (1988), p. 59. Cabe precisar que este futuro incumplimiento está fundado en un cambio de las circunstancias patrimoniales de los contratantes que hace evidente el peligro de obtener la contraprestación, mas no incluye la declaración anticipada de no querer cumplir como sí lo prevén ciertos instrumentos internacionales, como se mencionará más adelante. La jurisprudencia italiana mayoritaria asimila tal declaración al incumplimiento mismo, de allí que no se dude en la procedencia de la excepción de contrato no cumplido propiamente tal, dando cuenta de los anterior Bigliazzi (1988), pp. 28 y ss.

En el derecho alemán, encontramos el $\$ 321$ del BGB, norma que habilita al obligado en primer lugar para negar la prestación que le incumbe, cuando luego de la celebración del contrato bilateral se ponga de manifiesto que su derecho a la contraprestación peligra por la escasa capacidad de la contraparte, a menos que la prestación se efectúe o se preste garantía para ello. EnNECCERUS aclara que dicho artículo solo sería aplicable a los menoscabos patrimoniales que tuvieran lugar después de la conclusión del contrato y que la excepción en este caso "solo tiene una finalidad de aseguramiento y, por tanto, caduca si la otra parte presta 
ha relacionado con esta excepción preventiva y que nuestra jurisprudencia considera son una manifestación de la excepción de contrato no cumplido. Así la Corte Suprema, luego de referirse al tenor de los artículos 1551 y 1552 afirma: "Rebasando su supeditación a las situaciones vinculadas con la mora, puede sostenerse -y asi lo ha entendido la jurisprudencia y la mayor parte de la doctrina- que el artículo 1552 recién transcrito consagra en nuestro ordenamiento la excepción de inejecución asimismo conocida como "exceptio non adimpleti contractus"; a cuyos efectos también alude el mismo Código, a propósito de los contratos de compraventa y permuta, en sus artículos 1826 inciso $3^{\circ}, 1872$ y 1980 [sic]" 15 .

Las disposiciones referidas se sitúan, por una parte, a propósito del contrato de compraventa, los artículos 1826 y 1872 del CC. El primero de ellos, en su inciso cuarto, prevé el derecho del vendedor de suspender la entrega si, luego de celebrado el contrato, mengua considerablemente la fortuna del comprador, de modo que se halle en peligro inminente de perder el precio, a menos que este pague o asegure el pago; y el segundo, en su inciso segundo, faculta al comprador para suspender el pago depositando el precio con autoridad de la justicia, si fuese turbado en la posesión o prueba la existencia de una acción real de la que no le dio noticia el vendedor al tiempo de la celebración del contrato, hasta que cese la turbación o se afiance las resultas del juicio ${ }^{16}$. A lo anterior se suma la

caución”. Enneccerus, Ludwig (1953). Tratado de derecho civil. Traducción de Blas Pérez González y José Alguer. 2a edición. Tomo II. Barcelona: Bosch, p.169. En similar sentido Larenz, Karl (1958). Derecho de obligaciones. Traducción de José Santos Briz. Tomo II. Madrid: Revista de derecho privado, p.271.

15 Corte Suprema. 26 de julio de 2011. Rol No 9540-2009. "Exportadora de Frutas del Sur S.A. c. Servicios Integrales de Transporte S.A.”. Disponible en http://www.legalpublishing3. $\mathrm{cl} / \mathrm{maf} / \mathrm{app} /$ documentVM? \&src=laley\&lr=i0ad8181600000140c1678efbb28174e0\&docguid =i86AEABF32D7E16A1A66F4F94CD03DAF1 \&hitguid=i86AEABF32D7E16A1A66F4F9 4CD03DAF $1 \&$ epos $=1 \& \mathrm{td}=1 \&$ ao $=0$. i0ADFAB87B0C8D25381B0D0F03ED6FB4C\&searc hFrom $=\&$ savedSearch=false \&crumb-action=append [fecha de visita 19 de agosto de 2013] .

En la doctrina francesa, se estiman una manifestación de esta excepción preventiva el artículo 1613, que podemos considerar equivalente a nuestro artículo 1826 y el artículo 1653 , equivalente a nuestro artículo 1872. Malecki (1999), pp. 128 y pp. 257-258. Pillebout, Jean-Francois (1971). Recherches sur l'exception d'inexécution. Paris, L.G.D.J., pp. 244-245. Pinna (2003), pp. 34 y ss. En una dirección similar, a propósito del derecho belga Dubuison, Bernard; Trigaux, Jean-Marc (2001). "L'exception d'inexécution en droit belge". En Fontaine, Marcel; Viney, Geneviève (coordinadores): Les sanctions de l'inexécution des obligations contractuelles. Bruselas: L.G.D.J., pp. 108 a 109. Para los autores belgas la garantía que aporta la excepción de inejecución permitiría precaverse contra la inejecución previsible pero todavía no probada del contratante. Ahora bien, existe el riesgo de la oposición abusiva de la excepción desde que la simple amenaza de incumplimiento permitiría suspender la ejecución; por ello, y por analogía a las situaciones descritas en los artículos 1613 y 1653 del Código Civil belga, la excepción es solo procedente frente a una amenaza de inejecución a condición de que el excipiens demuestre que tiene razones importantes para creer que su cocontratante no podrá cumplir la obligación en el momento oportuno.

La doctrina clásica francesa no ve inconveniente en extender la aplicación del artículo 1613, en este sentido Cassin considera que la mala fe del contratante representa un peligro tan 
norma de la caducidad del plazo, el artículo 1496 del CC., disposición que a nuestro juicio nos aleja de la excepción preventiva y que nos lleva al terreno de la excepción de contrato no cumplido propiamente tal, ya que al operar la caducidad del plazo, en rigor, estaremos en presencia de una obligación que es exigible y no tendrá sentido cuestionar su procedencia porque el incumplimiento se habrá verificado.

La regulación en materia de compraventa, del derecho a suspender la propia prestación, presenta elementos comunes. En ambas hipótesis resulta probable razonablemente, por las circunstancias, que el incumplimiento se producirá y, además, opera si el deudor no garantiza o afianza que cumplirá con su prestación. Entendemos que en estos supuestos lo que realmente se afecta es la confianza en que el futuro cumplimiento se producirá.

En nuestra jurisprudencia, no encontramos sentencias que expresamente se hagan cargo de esta modalidad de la excepción de contrato no cumplido, no obstante invocarse por las partes algunas de las normas en las que expresamente se prevé ${ }^{17}$.

En el ordenamiento nacional es menester considerar, además, a la Convención de Viena sobre compraventa internacional de mercaderías, que contempla el derecho a suspender el contrato en los casos de incumplimiento previsible en su artículo 71, en los siguientes términos: “1) Cualquiera de las partes podrá diferir el cumplimiento de sus obligaciones si, después de la celebración del contrato, resulta manifiesto que la otra parte no cumplirá una parte sustancial de sus obligaciones a causa de: cia, o

a) un grave menoscabo de su capacidad para cumplirlas o de su solven-

b) su comportamiento al disponerse a cumplir o al cumplir el contrato.

2) El vendedor, si ya hubiere expedido las mercaderias antes de que resulten evidentes los motivos a que se refiere el párrafo precedente, podrá oponerse a que las mercaderías se pongan en poder del comprador, aun cuando este sea tenedor de un documento que le permita obtenerlas. Este párrafo

grande como la insolvencia de la otra parte, pues por muy solvente que sea, esa parte busca siempre el medio de recoger las ventajas esperadas del contrato, sin cumplir sus propias promesas Cassin (1914), pp. 550 y ss.

En el derecho italiano, la insolvencia del deudor o la ausencia o pérdida de las garantías aparecen vinculadas a la caducidad del plazo que beneficia al deudor, artículo 1186 del Código civil italiano, que difiere del tenor del artículo 1461 que regla la excepción preventiva fundada en el cambio de las circunstancias patrimoniales de los contratantes. Se da una supuesta identidad de fundamento que haría a la primera inutilizable, sin embargo, la doctrina entiende que para que opere la excepción de incumplimiento preventiva la situación patrimonial del deudor, su cambio, es menos grave. Véase Bigliazzi (1988), pp. 25-27.

17 Sentencia de la Corte de Apelaciones de Santiago. 11 de septiembre de 2001. Rol No 3589-1999. “Inmobiliaria Esarvic S.A. con Inv. Torre Alameda S.A.”. Disponible en http:// vlex.com/vid/inmobiliaria-esarvic-s-torre-alameda-32113240?ix_resultado $=1.0 \&$ query\% 0 B $\mathrm{q} \% 5 \mathrm{D}=$ Inmobiliaria+Esarvic+ [fecha de visita 19 de agosto de 2013]. 
concierne solo a los derechos respectivos del comprador y del vendedor sobre las mercaderías.

3) La parte que difiera el cumplimiento de lo que le incumbe, antes o después de la expedición de las mercaderias, deberá comunicarlo inmediatamente a la otra parte y deberá proceder al cumplimiento si esa otra parte da seguridades suficientes de que cumplirá sus obligaciones" 18.

En la redacción de la disposición, en la Convención, se intentó remarcar su carácter objetivo, debe resultar evidente que una parte no cumplirá con sus obligaciones, sin que se exija gravedad -en los términos de la convención, un incumplimiento esencial-, como sí acontece para ejercer el remedio resolutorio, conforme al artículo $72^{19}$; disposición que se aplicará solo en la medida que la otra parte no de seguridades suficientes de que efectuará el cumplimiento ${ }^{20}$. Será evidente en aquellos casos de insolvencia del deudor o cuando manifiesta claramente su voluntad de no querer cumplir o demuestra desinterés o escasa actividad, aunque no se agote en ellos porque la norma comprende genéricamente como causal, un grave menoscabo de su capacidad para cumplir las obligaciones que emanan del contrato $^{21}$. Cabe tener presente que el ejercicio de este derecho está subordinado a un requisito formal: el deber de comunicarlo

18 Esta disposición emana del artículo 73 ULIS (Convention relating to a Uniform Law on the International Sale of Goods), en este sentido, Ziegel, Jacob (1984). "The Remedial Provisions in the Vienna Sales Convention: Some Common Law Perspectives”. En Bender, Matthew: International Sales: The United Nations Convention on Contracts for the International Sale of Goods. New York: Galston \& Smit ed., pp. 9-43. Bennetr, Trevor (1987). "art.71”. En Bianca-Bonell: Commentary on the International Sales Law. Milan: Giuffrè, pp. 513-524, el autor ahonda en los antecedentes de la redacción actual del artículo 71 de la Convención. Mismo sentido Honnold, John (1999). Uniform Law for International Sales under the 1980 United Nations Convention. 3a ed. Holanda: Kluwer Law International, pp. 426-436.

19 Diferencia los requisitos y efectos de los artículos 71 y 72 de la Convención de Viena sobre compraventa internacional de mercaderías Ziegel, Jacob (1981). "Report to the Uniform Law Conference of Canada on Convention on Contracts for the International Sale of Goods". Disponible en: http://www.cisg.law.pace.edu/cisg/text/ziegel71.html [fecha de visita 19 de agosto de 2013].

Hace presente su carácter objetivo también BennetT (1987), pp. 513-524.

Parte de la doctrina de todas formas exige que el incumplimiento tenga una cierta importancia para que pueda operar este derecho de suspensión, en este sentido Calvo Caravaca, Alfonso-Luis (1998). “Comentario al art.71”. En Díez-Picazo, Luis (director): La compraventa internacional de mercaderías. Madrid: Editorial Civitas S.A., p. 563.

20 Estas seguridades o garantías, indica la doctrina, deben evidenciarse en acciones concretas que dependerán del caso, sin que baste una declaración en el sentido de que se pretende cumplir oportunamente con la prestación, Honnold (1999). Calvo precisa sus características: 1) es una noción autónoma porque no se identifica con el concepto de seguridad o garantía de las legislaciones nacionales. 2) Es imprescindible ya que en principio ningún contratante está obligado a otorgar garantías. 3) Es proporcional a la situación concreta de que se trate. Calvo (1998), p. 568.

21 La doctrina menciona como ejemplos aquellos casos en que existe una insuficiente capacidad del vendedor para entregar las mercaderías si se ha visto afectado por una huelga que es probable que continué por algún tiempo; si el comprador incumple su obligación de pagar al vendedor respecto a otros contratos que los ligan, así BennetT (1987), pp. 513-524. 
inmediatamente a la otra parte. De manera similar a lo previsto por la Convención de Viena, este derecho es reconocido en los Principios de Derecho contractual europeo y los Principios de Unidroit y el Marco común de referencia ${ }^{22}$.

Por nuestra parte, no vemos mayores objeciones en reconocer la procedencia de una excepción de incumplimiento contractual preventiva basándonos principalmente en el fundamento de la institución, el principio de ejecución simultánea de las obligaciones bilaterales, el que se verá afectado, si resulta claro que la otra parte no cumplirá; y su naturaleza jurídica, una excepción sustantiva que opera como mecanismo de defensa del deudor. No nos parece óbice a este reconocimiento general que nuestro legislador solo lo haya previsto en materia de compraventa y acotado a ciertas obligaciones que de ella pueden emanar, ya que entendemos que en los demás casos, estamos en presencia de un vacío o laguna legal. Para colmar dicha laguna nos parece adecuado acudir a la analogía, para extraer el principio subyacente de las hipótesis expresamente regladas, y a los principios generales del derecho, dentro de ellos, la equidad y la buena $\mathrm{fe}^{23}$. Lo anterior, estimamos, nos permite dotar de contornos a esta modalidad de excepción de contrato no cumplido.

El supuesto en el que procedería sería aquellos en que exista una reducida probabilidad de que el cumplimiento pueda verificarse, por las circunstancias en las que se encuentra el deudor, que pueden ser de distin-

22 En el caso de los Principios de derecho contractual europeo, artículo 9.201 se refiere al derecho a suspender el cumplimiento, en lo que nos interesa, en los siguientes términos "(2) Una parte puede igualmente suspender el cumplimiento mientras resulte evidente que existirá incumplimiento de la otra parte una vez que la obligación de esta última haya vencido", y el Marco común de referencia, artículo 3:401 (2): "A creditor who is to perform a reciprocal obligation before the debtor performs and who reasonably believes that there will be non-performance by the debtor when the debtor's performance becomes due may withhold performance of the reciprocal obligation for as long as the reasonable belief continues. However, the right to withhold performance is lost if the debtor gives an adequate assurance of due performance"

Los Principios de Unidroit, difieren porque expresamente exigen gravedad del incumplimiento para que pueda ejercerse este derecho. El artículo 7.3.4 dispone: "Una parte que crea razonablemente que habrá un incumplimiento esencial de la otra parte puede reclamar una garantía adecuada del cumplimiento y, mientras tanto, puede suspender su propia prestación. Si esta garantía no es otorgada en un plazo razonable, la parte que la reclama puede resolver el contrato".

23 Estamos en presencia de un vacío o laguna legal que se produce ante la ausencia de una solución que haya proporcionado el legislador a la materia y que el juez se verá en la necesidad de colmar por aplicación del principio de inexcusabilidad. Para colmarla la doctrina usualmente acude a la analogía, los principios generales del derecho, la equidad e incluso a la costumbre. Sobre el particular véase SQuella, Agustín (2011). Introducción al Derecho. 2a Edición. Santiago: Editorial Jurídica de Chile, pp. 663 y ss. Acerca de los principios generales del derecho, en especial su naturaleza y funciones, puede consultarse, Terrazas, Juan David (2004). "Algunas consideraciones sobre los principios generales del derecho y un breve análisis de su aplicación en el ordenamiento jurídico chileno". Revista de Derecho Universidad Católica del Norte. Año 11 No 1, pp.133-159. 
ta índole: la voluntad manifestada del deudor de no querer cumplir, económicas, de funcionamiento de su organización, por mencionar algunos ejemplos y que en definitiva se traducen en una pérdida de confianza de que la prestación se realizará. Resulta así altamente probable que el incumplimiento se producirá aunque no se haya materializado y por ello, nos parece equitativo y fundado en la buena fe, que aquel contratante que, en principio no puede oponer la excepción de contrato no cumplido porque la prestación de su cocontrantante aún no es exigible, pueda hacerlo.

Estimamos que al exigir, como requisito para su procedencia, la pérdida de confianza en que la prestación se ejecutará oportunamente evita su ejercicio abusivo, es decir, que se transforme en un instrumento que emplee una de las partes para dilatar o entorpecer su propio cumplimiento fundado en el incumplimiento previsible de su cocontratante; y no equipara, en cuanto al incumplimiento, a esta modalidad de la excepción de contrato no cumplido con la resolución. En definitiva se trata de instituciones que siguen teniendo funciones y finalidades diferentes una vez que se ha verificado el incumplimiento ${ }^{24}$.

\section{2) EL INCUMPLIMIENTO Y SU GRAVEDAD}

La doctrina ha puesto de relieve, desde antaño, que un importante problema vinculado con la excepción de contrato no cumplido es la gravedad del incumplimiento, que suele ser exigido para admitir su procedencia. El análisis de este requisito resulta más plausible tratándose de la exceptio non rite adimpleti contractus, en los casos de cumplimiento defectuoso $^{25}$. Para una adecuada comprensión del alcance de las sentencias que se pronuncian acerca de este requisito nos parece relevante precisar

24 Funda también su procedencia en la pérdida de confianza Pinna (2003), pp. 43 y ss.

Reconocemos que hemos postulado, en otra oportunidad, tres criterios para determinar un incumplimiento resolutorio, uno de los cuales es precisamente la pérdida de confianza. Sin embargo, se mantienen importantes diferencias, por lo pronto porque la coincidencia es solo parcial -existen dos criterios más que no coinciden- y que el énfasis en la resolución está en el comportamiento doloso o deliberado del deudor que conlleva a la pérdida de confianza, mientras que en esta modalidad de la excepción de contrato no cumplido es más amplio, la pérdida de confianza se centra en que la prestación no se ejecutará aunque no exista dolo o culpa grave en el actuar del deudor. Con detalle acerca del alcance de estos criterios en materia de resolución, véase Mejías Alonzo, Claudia (2011). El incumplimiento resolutorio en el Código civil. Santiago: Legal Publishing, pp. 209 y ss.

25 Hacemos presente que la gravedad es un requisito adicional a la noción de incumplimiento que entendemos es amplia y objetiva. En este sentido, Mejías Alonzo, Claudia (2008). "El incumplimiento contractual y sus modalidades", en Guzmán Brito, Alejandro (editor): Estudios de Derecho civil III. Santiago: Editorial LegalPublishing, pp. 459-478. Vidal OlivaRES, Álvaro (2007). "Cumplimiento e incumplimiento contractual en el Código civil. Una perspectiva más realista”. Revista Chilena de Derecho. Nro. 34, Vol.1, pp. 41-59. Bigliazzi (1988), pp. 18 y ss. 
previamente cuál es la razón de esta exigencia, para luego centrarnos en responder cuándo se entiende por nuestros tribunales que el incumplimiento es grave. En ello ahondaremos en las líneas que siguen.

\section{1.) Fundamento de LA EXIGENCiA DE GRAVEDAD DEL INCUMPLIMIENTO}

La razón de la exigencia de gravedad, nos parece, descansa en la asimilación de los requisitos de la excepción de contrato no cumplido con los requisitos de la resolución, en tanto efectos particulares de los contratos bilaterales. Es en atención a esto que se exige, para la excepción de contrato no cumplido, la misma gravedad que en materia de resolución. Se estima que el problema es el mismo simplemente cambia de escenario $^{26}$. De allí entonces que encuentren un fundamento común: la causa, mencionándose usualmente además, la buena fe y la equidad. Así la Corte de San Miguel ha sostenido que esta excepción "universalmente conocida como exceptio non adimpleti contractus, institución característica de los contratos bilaterales o sinalagmáticos, cuya fundamentación radica en la teoría de la causa y el principio de la buena fe que debe presidir la ejecución de los contratos" 27 .

26 Fueyo Laneri, Fernando (2004). Cumplimiento e incumplimiento de las obligaciones. $3^{\mathrm{a}} \mathrm{ed}$. Santiago: Editorial Jurídica de Chile, p. 241. CAPrile (2012), el autor concluye "Nos parece evidente que el presupuesto o tipo de incumplimiento exigido para ejercer la acción resolutoria u oponer la excepción de inejecución debe ser, al menos en este aspecto, idéntico".

En España, refiriéndose a la precedencia de la excepción de contrato no cumplido en los casos de ejecución deficiente de la prestación que se debe al demandado, denuncia y califica de peligrosa la doctrina que exige la gravedad, porque hace operar la exceptio solo en los casos en que podría operar la resolución; aun cuando se trata de remedios diferentes que la historia ha demostrado que no tienen por qué coincidir. Cruz Moreno (2004), pp. 63 y ss. En la misma dirección Rodríguez-Rosado, afirma que la gravedad es un requisito que surgió en el ámbito de la resolución y que allí tiene sentido, pero que resulta desorbitado cuando se aplica a la excepción de incumplimiento. Rodríguez-Rosado (2013), p. 100.

En el derecho inglés, en cambio, la excepción de contrato no cumplido se considera la primera etapa hacia la resolución y por ello responden a un mismo criterio de gravedad, lo que se debe a la ausencia de distinción entre estas dos instituciones. Véase, Popineau-DehauLLON, Catherine (2008). Les remèdes de justice privée à l'inexécution du contrat étude comparative. Paris: L.G.D.J., pp. 87-88. Whittaker, Simon (2001). "Les sanctions de l'inexécution des contrats droit anglais". En Fontaine, Marcel; Viney, Geneviève (coordinadores): Les sanctions de l'inexécution des obligations contractuelles. Bruselas: L.G.D.J., pp. 981 y ss. En el derecho alemán es similar toda vez que el tenor del $\$ 320$ (2) se interpreta dando lugar a la excepción solo si el incumplimiento lo es de una obligación que se considera como principal. Popineau-Dehaullon (2008), pp. 88-89. Treitel (2004), pp. 327-333.

27 Corte de Apelaciones de San Miguel. 22 de mayo de 1997. Rol No 1042. "Luisa Brousset con Santiago Aravena”. Disponible en http://www.legalpublishing3.cl/maf/app/docum entVM? \&src=laley \&lr=i0ad6007a00000140ccc148a070a51fc7\&docguid=i0ADFABE1B2 E4374181B2E8716D6AEFFA\&hitguid=i0ADFABE1B2E4374181B2E8716D6AEFFA\& epos $=1 \& \mathrm{td}=1 \&$ ao =o.i0ADFAB87B0C8D25381B0D0F03ED6FB4C\&searchFrom=\&saved 
A nuestro juicio, sin embargo, el verdadero fundamento de la institución descansa en el principio de ejecución simultánea de las obligaciones emanadas de un contrato bilateral ${ }^{28}$. Y, desde esa perspectiva, si el acreedor no cumple con sus obligaciones no puede pretender que el deudor cumpla con los suyas; el deudor se ampara precisamente para no cumplir en el incumplimiento del acreedor. Por esto, el principio de ejecución simultánea permite descartar la procedencia de la excepción de contrato no cumplido en aquellos casos en que el incumplimiento que se atribuye al actor no tiene relación con el contrato que las partes han celebrado y que el deudor incumplió. En este sentido, la sentencia arbitral del año 2001 sostuvo que: "los incumplimientos que pueden servir de fundamento a la excepción de contrato no cumplido deben ser precisamente infracciones de obligaciones emanadas del contrato, en favor de quien alega la excepción, cometidas por su contraparte. No se trata, por tanto, de cualquier incumplimiento en que pueda incurrir la otra parte. De la lista de incumplimientos que los demandados achacan a XXX-acreedor-, los siguientes no tienen nada que ver con el contrato: a) el incumplimiento de los objetivos de incorporación; b) la ausencia de affectio societatis; c) el abuso de posición dominante; d) la administración ruinosa de la demandada; y f) incumplimiento del art. 44 de la ley de sociedades anónimas (conflicto de intereses). Estos incumplimientos, en caso de existir, serian reprensibles y podrian dar lugar a acciones que tiendan a remediarlos, pero no pueden servir de fundamento a la excepción de contrato no cumplido" ${ }^{29}$.

Search=false\&crumb-action=append [fecha de visita 20 de agosto de 2013]. Siguiendo expresamente al profesor Luis Claro Solar, identifica también a la causa como fundamento de la institución, Corte Suprema. Rol No 9540-2009, considerando vigésimo.

En doctrina Luis Claro Solar, René Abeliuk, Pablo Rodríguez y Jorge López establecen como fundamento de la excepción de contrato no cumplido la equidad, Claro Solar (1978), pp. 787-788. López Santa María (2010), p. 490. Rodríguez Grez, Pablo (2004). "Sobre la excepción del contrato no cumplido". Revista Actualidad Jurídica, № 9, pp. 123 y ss. Abeliuk (2010), p. 941. Fueyo acude a la buena fe, Fueyo (2004), p. 127; nuestros tribunales, Corte de Apelaciones de Concepción. 20 de junio de 2011. Rol No 642011. Disponible en http://vlex.com/vid/-287419723?ix_resultado $=1.0 \& q u e r y \% 5 \mathrm{~Bq} \%$ $5 \mathrm{D}=287419723$ [fecha de visita 20 de agosto de 2013]. La Corte Suprema también acude a la buena fe y equidad, como fundamento de la excepción, en el conocido caso de Incomin S.A. con Enami, Corte Suprema. 31 de marzo de 2003. Rol No1594-2001. "Incomin S.A. con Enami”. Disponible en http://vlex.com/vid/incomin-enami-32032899?ix_resulta $\mathrm{do}=1.0 \&$ query $\% 5 \mathrm{~Bq} \% 5 \mathrm{D}=32032899$ [fecha de visita 20 de agosto de 2013], considerando cuadragésimo. En la misma dirección Corte Suprema. 29 de septiembre de 2009. Rol No 2763-2003. Disponible en http://vlex.com/vid/-333768310?ix_resultado=1.0\&query\%5Bq $\% 5 \mathrm{D}=333768310$ [fecha de visita 20 de agosto de 2013].

28 Sobre el particular véase MejíAs (2013).

29 Sentencia arbitral. 20 de junio de 2001. Rol No 2012. Disponible en http://www. camsantiago.com/sentencias/IndiceGral_2011/212-01.pdf [fecha de visita 20 de agosto de 2013], considerando nro. 60. En este caso una sociedad anónima demanda para obtener el cumplimiento forzado de las obligaciones que nacieron del contrato marco celebrado entre las partes, con indemnización de perjuicios y costas. La demandada dedujo demandas 
De manera similar acontece en la sentencia de la Corte de San Miguel, que rechaza la procedencia de la excepción de contrato no cumplido basado en que "no constituyendo la gestión conducente a lograr la recepción definitiva del inmueble ante el competente organismo municipal, un elemento que sea de la esencia del contrato de corretaje sobre venta de una propiedad inmobiliaria o que se entiende pertenecerle como ingrediente natural, sin necesidad de una cláusula especial, la única forma de integrarlo a su estructura es a través de una estipulación expresa de las partes; situación esta que no ha ocurrido en la especie, de acuerdo con los antecedentes que obran en el expediente; de manera que no es lícito a la demandada oponer la excepción en referencia para enervar la pretensión de la actora". En definitiva no existiendo en realidad un incumplimiento que atribuirle a la actora, porque el cumplimiento de su obligación no comprendía obtener la recepción definitiva del inmueble, no puede prosperar la excepción de contrato no cumplido ${ }^{30}$.

reconvencionales de resolución del contrato marco, basada en los graves incumplimientos del actor, y de nulidad de los contratos de compraventa de acciones, por ser estos simulados; en su contestación se opuso la excepción de contrato no cumplido. Hacemos presente que el considerando No 53 confunde la excepción con la compensación en mora, a partir del tenor del artículo 1552 del Código Civil.

Se precisa, además, que en el considerando No 56, al no existir controversia respecto al incumplimiento del deudor, solo "puede ser materia de controversia determinar si ese incumplimiento es justificado o no. Y para que este incumplimiento resulte justificado es necesario que él sea la consecuencia del recíproco incumplimiento de la demandante". No ahondamos mayormente en él porque la decisión del tribunal se centra en el considerando No 60 ya reproducido.

30 Corte de Apelaciones de San Miguel. Rol No 1042, considerando undécimo de la apelación. En los hechos se demandó el cobro de honorarios por la venta de un inmueble, comisión que se hizo efectiva conforme a los contratos acompańados en el juicio, al momento de la suscripción del contrato de promesa. La demandada opuso la excepción de contrato no cumplido y la hizo consistir en la circunstancia de que la demandante no había cumplido con el encargo que le hiciera el dueño del inmueble, en orden a que gestionase la recepción municipal de la propiedad, retrasándose con ello el crédito hipotecario con que se había de financiar la operación de venta, por lo que dicho propietario declaró resuelta su relación comercial con ella, encomendado la gestión del negocio a otro corredor de propiedades, quien recibió, en definitiva, la comisión correspondiente.

En el mismo sentido, la Corte de Apelaciones de Puerto Montt ha sostenido: "La excepción será rechazada desde que la parte demandada se está refiriendo indudablemente al contrato de trabajo como administrador del hotel al que se le puso término mediante carta de aviso suscrita por don René Schmidt materia que ha quedado excluida de esta litis; ya se ha dicho que se acredita una relación contractual como supervisor en la construcción del lodge con la empresa Southern Chile Expeditions S.A. distinta del contrato laboral de administrador". CORTE DE Apelaciones de Puerto Montt. 4 de diciembre de 2007. Rol No 240-2006. "Schoenahuer Kent Lloyd con Souther Chile Expeditions S.A y otro". Disponible en http://vlex. $\mathrm{com} / \mathrm{vid} /-332882654$ ? ix_resultado=1.0\&query\%5Bq\%5D=Southern+Chile+Expeditions+ S.A [fecha de visita 20 de agosto de 2013]. En similar dirección Sentencia arbitral. 29 de diciembre de 2009. Rol No 1144-2009. Disponible en http://www.camsantiago.com/ sentencias/IndiceGral_2011/1144\%20Bascu\%C3\%B1\%C3\%A1n\%20Vald\%C3\%A9s.pdf [fecha de visita 20 de agosto de 2013], considerando nro. 63. 
Centrándonos en la exigencia de gravedad del incumplimiento, es relevante considerar que ella no está presente en el artículo 1552 del Código civil, norma que, además, a nuestro juicio, solo consagra implícitamente la institución al ser una clara manifestación de su fundamento. Podrá estimarse que, en estricto sentido, la situación no es muy distinta en materia de resolución al tenor del artículo 1489 -donde la doctrina actual no duda de esta exigencia-. Nos parece, sin embargo, que estas disposiciones deben ser leídas considerando el conjunto de normas que en el Código civil reglan la temática del incumplimiento y principalmente la naturaleza jurídica que tiene la institución. En el caso de la excepción de contrato no cumplido se trata de una verdadera excepción que tiene por finalidad obtener el cumplimiento del contrato, cuyo principal efecto es paralizar la pretensión de cumplimiento. En este contexto, no vemos razones que justifiquen exigir la gravedad del incumplimiento para este mecanismo que tiene un alcance y finalidad distinta que la resolución ${ }^{31}$.

Creemos que la excepción de contrato no cumplido procede, en principio, ante cualquier incumplimiento. Ciertamente tiene un límite: su ejercicio no debe ser contrario a la buena fe. Esto deberá verificarse por el operador jurídico al analizar el último de los requisitos, la buena fe de quien deduce la excepción de contrato no cumplido ${ }^{32}$. Nuestros tribuna-

31 En la misma dirección Popineau-Dehaullon (2008), pp.92, 96. Destacando la importancia de distinguir la exceptio de la resolución, respecto de la exigencia de la gravedad, precisamente por los efectos diversos que producen -el carácter no definitivo de la primera-. MALECKI (1999), pp. 280 y ss. Consideramos que sigue esta postura, aunque no compartimos la terminología Rodríguez-Rosado al afirmar: "A mi juicio, contrario al que ha expresado el Tribunal Supremo en varias Sentencias, no hace falta que las obligaciones que se oponen una a otra para conseguir el efecto paralizador de la exceptio non adimpleti contractus hayan de ser dos principales. Cabe igualmente oponer el incumplimiento de una obligación accesoria frente a una demanda dirigida a una prestación principal, o a la inversa [...]. RodríGUEZ-Rosado (2013), p.99. Espín, por su parte, reconoce que el campo de aplicación de la excepción de contrato no cumplido es más amplio que el de la resolución, Espín (1964), pp. 556-557.

Bianca, en la doctrina italiana no considera que el límite de la buena fe que prevé el artículo 1460 del Código Civil sea una exigencia de un incumplimiento de no escasa importancia -art.1455-, estima que ello implicaría introducir arbitrariamente un presupuesto que la ley prevé para la resolución del contrato en atención al carácter definitivo y grave de este remedio, Bianca, C.M (1992). "Eccezione d'inadempimento e buona fede". En Il contratto. Silloge in onore di G. Oppo. Padova, pp. 517-518. En similar sentido Realmonte, considera que emplear este criterio restringe el alcance de la excepción a pesar que la fórmula del legislador es mucho más amplia, pudiendo producirse perfectamente supuestos en los que el incumplimiento es de escasa importancia y la oponibilidad de la excepción no sea contraria a la buena fe, Realmonte (1965), p. 230.

32 En la doctrina española Rodríguez-Rosado, acude a la buena fe para evitar abusos ante la procedencia de la exceptio frente a cualquier incumplimiento. RodríGuez-Rosado (2013), p. 100. Más adelante agrega, p. 101, que la excepción de contrato no cumplido busca mantener el equilibrio contractual entre las partes, presionando a cumplir la propia prestación si se quiere obtener la de la otra parte. Popineau-Dehaullon (2008), p. 96. En el derecho francés, Carbonnier menciona la buena fe como una restricción a su procedencia, aunque 
les, al menos implícitamente acogen esta distinción. Así la Corte de Apelaciones de San Miguel, luego de precisar que la excepción de contrato no cumplido exige un incumplimiento de cierta envergadura, ya que de lo contrario se atentaría contra la buena fe, agrega que la demandada sostiene en su escrito de apelación que "el inmueble arrendado no se encontraba en estado de servir para el fin para el cual habia sido arrendado, vale decir, para un fin habitacional".

Así las cosas, si la arrendataria estimaba que los defectos que atribuye al inmueble objeto del contrato de locación eran de tal envergadura que impedían dar al inmueble el destino para el cual lo habia arrendado, debió poner término al contrato; sin embargo, no existe constancia alguna de que haya manifestado su voluntad en aquel sentido" 33 . Nos parece que el tribunal distingue entre un incumplimiento de mayor entidad que hace procedente la resolución y otro, que es de menor entidad, que hace procedente la excepción de contrato no cumplido. Sí manifestamos que en estos casos de incumplimiento grave, lo razonable es permitirle al deudor, acreedor de la obligación recíproca, optar por ejercer un remedio u otro y no privarle de uno de estos mecanismos como se desprende del considerando de la Corte.

Podría pensarse que con ello se introduce un elemento inútil de diferenciación con la resolución que simplemente dificulta la aplicación de la institución, teniéndose en cuenta que tratándose de esta aún no hay uniformidad de criterios en las decisiones de nuestros tribunales de justicia. Incluso podrá pensarse que con la exigencia de buena fe se esconde o

no queda claro si es como sinónimo de gravedad o realmente es considerado como límite, Carbonnier, Jean (2004). Droit Civil. Paris: Presse Universitaires de France, pp. 22452246.

En la doctrina italiana se diferencia la gravedad del incumplimiento que se exige a partir del tenor del artículo 1455 -incumplimiento de no escasa importancia en atención al interés de otra parte-, del límite que se impone a la excepción de contrato no cumplido a partir del artículo 1460 inciso $2^{\circ}$, si su ejercicio es contrario a la buena fe. Bigliazzi (1988), pp. 31 y ss. Realmonte (1965), pp. 230-233.

En la doctrina francesa también se menciona a la buena fe como requisito para que prospere la excepción. Por todos Cassin (1914), pp. 565-580. Pillebout (1971), p. 221. Ghestin (2001), pp. 41-45 (para este autor parece identificarse más bien con la gravedad del incumplimiento).

33 Corte de Apelaciones de San Miguel. 7 de septiembre de 2012. Rol No 486-2012. "Moyano Sepúlveda Kathia Pamela con González Pereira Eduardo Gastón”. Disponible en http://vlex.com/vid/-400957010?ix_resultado=1.0\&query\%5Bq\%5D=400957010 [fecha de visita 20 de agosto de 2013], considerando séptimo.

Las partes celebraron un contrato de arrendamiento sobre un inmueble. Se demandó la terminación del contrato de arrendamiento y reconvenciones de pago por rentas insolutas. En su contestación el demandado opuso la excepción de contrato no cumplido. En primera instancia la excepción fue rechazada por considerarse improcedente. 
disfraza la exigencia de gravedad, llevándonos nuevamente al terreno de la resolución, como lo hace parte de la doctrina ${ }^{34}$.

Opinamos que ello no es así, pues la aplicación práctica de la institución revela que tras la exigencia de gravedad, como veremos a continuación, la mayoría de las veces lo que se quiere impedir es un ejercicio contrario a la buena fe; por lo tanto, no se estaría introduciendo un criterio que nuestros tribunales no hayan empleado usualmente para resolver las controversias, simplemente lo estamos explicitando. Además, la diferenciación nos parece útil toda vez que estamos en presencia de remedios sinalagmáticos diferentes, con requisitos, finalidades y efectos claramente distinguibles.

Con lo expresado precedentemente no pretendemos negar que existe un terreno común en esta materia, en el entendido que todo incumplimiento que da lugar a la resolución faculta al deudor para oponer la excepción de contrato no cumplido, mas ello no obsta a que pueda prosperar en otras hipótesis, donde encontramos su terreno propio de aplicación, y en estas, la buena fe opera como límite 35 .

34 En la doctrina nacional, Fueyo si bien plantea que deben aplicarse los mismos criterios que en materia de resolución, reitera el llamado a la buena fe, FueYo (2004), p. 241. Alessandri, Somarriva y Vodanovic, emplean terminología que evoca la resolución, obligaciones de la esencia y de la naturaleza; sin embargo, al precisar el incumplimiento que permite excepcionarse se inclinan simplemente por el incumplimiento de lo pactado, reconociendo sí como límite el artículo 1546 -la buena fe objetiva-, Alessandri, Arturo; Somarriva, Manuel y Vodanovic, Antonio (2004). Tratado de las obligaciones. 2a ed. Santiago: Editorial Jurídica de Chile. Vol. 1, pp. 299-300. Pizarro, por su parte reconoce que la mayoría de los autores exigen que la excepción sea opuesta de buena fe, en aplicación del artículo 1546 del Código Civil, mas considera que ello se manifiesta en la necesidad que el incumplimiento sea de una gravedad que justifique la suspensión del cumplimiento de las obligaciones. De todas formas no nos parece claro el planteamiento del autor porque, conforme a lo que indica más adelante, vuelve sobre la buena fe más bien como límite, para descartar cierto incumplimiento; en efecto indica: "La necesidad de exigir una gravedad relevante en el incumplimiento dice relación con evitar el abuso de la excepción al interponerse por incumplimientos ínfimos o insignificantes que repugnan a la buena fe contractual" y agrega que el mismo problema se presenta en materia de resolución Pizarro (2005), pp. 196.

Cruz Moreno refiriéndose a cómo la jurisprudencia española ha entendido que el ejercicio de la buena fe no sea contrario a la buena fe, indica que se ha rechazado la excepción cuando la prestación no ejecutada por el demandante tiene carácter accesorio, o cuando refiriéndose a una obligación principal, el incumplimiento fuese de escasa gravedad; concluye que se exigen los mismos requisitos que para la resolución. Cruz Moreno (2004), pp. 70 y ss.

35 Es por ello que en doctrina se ha sostenido que siempre que sea posible pedir la resolución del contrato el ejercicio de la excepción de contrato no cumplido será conforme a la buena fe. Cruz Moreno (2004), p. 79.

No debe perderse de vista que la buena fe es recogida en el derecho comparado como un límite a la procedencia de la excepción, es lo que acontece por ejemplo, en el derecho alemán $(\$ 320)$, el derecho italiano (art.1460). En el derecho italiano, Bianca vincula el límite de la buena fe con el ejercicio abusivo de la excepción, manifestaciones de ello serían los siguientes casos: a) si el cumplimiento del deudor es inexacto y no se puede remediarlo, se considera abusiva su procedencia de cara a la finalidad provisoria de la excepción; b) la excepción conlleva a una consecuencia excesivamente onerosa; c) el incumplimiento es de leve entidad 


\section{2) LA GRAVEDAD DEL INCUMPLIMIENTO EN LA JURISPRUDENCIA NACIONAL}

A continuación pretendemos indagar en el verdadero alcance tras la gravedad que parecen exigir nuestros tribunales para facultar al deudor a suspender provisionalmente su cumplimiento.

Resulta necesario aclarar que la mayoría de las sentencias que se hacen cargo de la gravedad del incumplimiento parten de la premisa de que, en rigor, tanto el acreedor como el deudor no han cumplido con sus prestaciones. Nos parece, además, importante consignar que no todas las sentencias en las que se invoca la excepción de contrato no cumplido se centran en el análisis de sus requisitos de procedencia, dentro de ellos la gravedad.

Si reparamos en aquellas sentencias que abordan el incumplimiento y su entidad, un importante número equiparan la exigencia de gravedad en materia de resolución y de excepción de contrato no cumplido, ya sea al considerar que el incumplimiento tiene una entidad suficiente (acudiéndose a los distintos criterios para que ella proceda, como por ejemplo si afecta la finalidad que el acreedor perseguía con la ejecución del contrato $^{36}$, o se trata de obligaciones de la esencia o de la naturaleza ${ }^{37}$ ); ya sea

y la excepción comporta la extinción de la obligaciones del excipiens; d) la excepción perjudica un derecho fundamental de la persona, BiAnCa (1992), pp. 522-530.

Acerca del incumplimiento que da lugar a la resolución, véase Mejías (2011). Consignamos que en materia de resolución nuestra jurisprudencia ha acudido a la buena fe como fundamento directo de la procedencia de la resolución y no para limitar su procedencia, en los casos que en el libro referido denominamos de pérdida de confianza.

36 Otras sentencias simplemente rechazan la excepción de contrato no cumplido por estimarse que el incumplimiento en que se funda no tiene trascendencia ni entidad suficiente. En esta dirección, Corte Suprema. 23 de mayo de 2013. Rol No 2152-2013. "Hernández Muñoz, Mauricio Eulogio con Scotiabank Chile”. Disponible en http://vlex.com/vid/ hernandez-mua-mauricio-scotiabank-chile-438375858?ix_resultado $=1.0 \&$ query $\% 5 \mathrm{~Bq} \%$ $5 \mathrm{D}=438375858$ [fecha de visita 23 de agosto de 2013].

37 Corte de Apelaciones de Arica. 29 de octubre de 2007. Rol No 311-2007. "Clotilde Crispin Quispe con Ilustre Municipalidad de Arica”. Disponible en http://www.legalpublishing3.cl/maf/app/documentVM? \&src=laley\&lr=i0ad8181500000140e0329df698215e49\& docguid=i0ADFABE1B1C92E8781B106BD16F2AA7B\&hitguid=i0ADFABE1B1C92E 87 81B106BD16F2AA7B \&epos $=1 \& \mathrm{td}=1 \&$ ao $=0$. i0ADFAB87B0C8D25381B0D0F03ED6FB $4 \mathrm{C} \&$ searchFrom $=\&$ savedSearch=false \&crumb-action=append [fecha de visita 23 de agosto de 2013], la Corte en su considerando décimo estableció: "Que de otra parte, de los términos de la cláusula tercera del contrato de concesión y de las bases administrativas de la propuesta pública, surge que la obligación esencial de la concesionaria era la de pagar oportunamente la renta por el uso y explotación del bien concesionado, cuyo valor seria de 60 Unidades Tributarias Mensuales durante el primer año y de 70 Unidades Tributarias Mensuales a partir del segundo año y hasta el término de la concesión, a la cual se agregan otras obligaciones de carácter accidental enumeradas en la cláusula sexta relativas al funcionamiento y mantención del bien entregado en concesión, entre las que se encuentra la de contratar un seguro de incendio. Si bien el artículo 1552 del Código Civil dispone que en los contratos bilaterales ninguno de los contratantes está en mora de cumplir lo pactado, mientras el otro no lo cumple por su parte, o no se allana a cumplir- 
implícitamente vinculando a la resolución con la excepción de contrato no cumplido. Solo excepcionalmente se relaciona expresamente la gravedad del incumplimiento con la exigencia de buena $\mathrm{fe}^{38}$.

Así, es manifestación de lo primero, la sentencia de la Corte Suprema que consideró que no se había infringido el artículo 1552 porque "la inejecución atribuida al acreedor demandante incide en una obligación relevante, de real trascendencia en el contrato cuyo incumplimiento en lo concerniente a las especificaciones técnicas convenidas llegaron al extremo que los bienes objeto del contrato resultaron ulteriormente inservibles para los fines que le son propios" 39 .

Lo en la forma y tiempo debidos, esta sanción se refiere únicamente a las obligaciones de la esencia $y$ de la naturaleza del contrato, pero no a las accidentales establecidas por las partes, por lo que si se alegan como incumplidas obligaciones accidentales materia del contrato, no podrían tener el efecto que contempla el citado artículo 1552".

38 Corte de Apelación de Santiago. 6 de agosto de 2008. Rol No2008-2004. "Dahm Oyarzún, Jorge con Fuentes Belmar, Juan”. Disponible en http://www.legalpublishing3.cl/maf/ app/documentVM? \&src=laley\&lr=i0ad8181600000140e03506b38967d2a5\&docguid=i1 AF679CBD2A7F7247754F2DC6D29D96B\&hitguid=i1AF679CBD2A7F7247754F2D C6D29D96B \&epos $=1 \& \mathrm{td}=1 \& \mathrm{ao}=0 . \mathrm{i0} 0 \mathrm{ADFAB} 87 \mathrm{~B} 0 \mathrm{C} 8 \mathrm{D} 25381 \mathrm{~B} 0 \mathrm{D} 0 \mathrm{~F} 03 \mathrm{ED} 6 \mathrm{FB} 4 \mathrm{C} \& \mathrm{se}$ archFrom=\&savedSearch=false\&crumb-action=append [fecha de visita 9 de septiembre de 2013]. En su considerandos tercero y cuarto se expresa: "Tercero: Que, cualquiera que sea el incumplimiento -total o parcial - la excepción de contrato no cumplido es procedente, requiriéndose solo la exigencia de un grado de importancia, gravedad o trascendencia del incumplimiento respectivo;

Cuarto: Que, las razones invocadas con ocasión de la alegación de la excepción de contrato no cumplido, se encuentran sustentadas por la aplicación del principio de la buena fe, lo cual conduce a una regulación de lo que se debe estimar por suficiente o bastante como grado de cumplimiento, de tal manera de que si este es insuficiente e inaceptable, se estará dando lugar en el evento de incumplimiento, a la excepción". Se hace presente que los hechos de este caso, por lo breve de la sentencia, no quedan claros y por ello no se consignan.

39 Corte Suprema. 24 de marzo de 2011. Rol No 3789-2009. "Fuentes Rodríguez, José Belisario con Canteras Lonco S.A". Disponible en http://www.legalpublishing3.cl/maf/app/doc umentVM? \&src=laley\&lr=i0ad8181500000140e03bbf571f7680d $3 \&$ docguid=i0066249D 187B4B95DE55C2D8A8C02667\&hitguid=i0066249D187B4B95DE55C2D8A8C02667 \&epos $=1 \& \mathrm{td}=1 \&$ ao $=0 . \mathrm{i} 0 \mathrm{ADFAB} 87 \mathrm{~B} 0 \mathrm{C} 8 \mathrm{D} 25381 \mathrm{~B} 0 \mathrm{D} 0 \mathrm{~F} 03 \mathrm{ED} 6 \mathrm{FB} 4 \mathrm{C} \& \mathrm{search} F r o m=\&$ sav edSearch=false\&crumb-action=append, considerando No 14 [fecha de visita 23 de agosto de 2013]. Se celebró un contrato de compraventa de dos semirremolques tolva los que fueron entregados mas no se pagó el precio. Se dedujo demanda ordinaria de cobro de pesos. El demandado en su contestación justifica su incumplimiento porque el demandante no fabricó lo pactado ni lo hizo dentro del tiempo estipulado, oponiendo la excepción de contrato no cumplido. De la prueba rendida, el tribunal de instancia concluye que eran efectivos los continuos desperfectos que afectaron a los semirremolques y la ausencia de condiciones de seguridad para su funcionamiento, de los que estaba en conocimiento el demandante, por ello acoge la excepción de contrato no cumplido. Apelada la sentencia, la Corte de Apelaciones de Concepción la confirma. Posteriormente se dedujo recurso de casación en el fondo, por infracción, entre otras disposiciones, del artículo 1552 del Código civil.

En similar dirección encontramos: a) Sentencia arbitral. 2 de enero de 2007. Rol No 622. Disponible en http://www.camsantiago.com/sentencias/IndiceGral_2011/622.pdf [fecha de visita 23 de agosto de 2013], considerando No 8. En este caso se demandó el cumplimiento de un contrato de prestación de servicios, pago de un estudio de factibilidad de un proyecto. Se probó en el juicio un incumplimiento relevante que afectaba la finalidad 
Manifestación de lo segundo, es la sentencia de la Corte de Apelaciones de La Serena que afirma "necesario es tener presente, en primer término, que para considerar la resolución por incumplimiento, es preciso exigir un grado de importancia, gravedad o trascendencia al incumplimiento respectivo; y luego, respecto a la excepción de contrato no cumplido, que la excusa válida de incumplimiento no podría ser posible admitirla, ante defectos $u$ omisiones irrisorias, inocuas e intrascendentes que no deben tener repercusión jurídica" 40 .

Existe otro grupo de sentencias en las que se descarta o acoge la procedencia de la excepción de contrato no cumplido fundado en el incumplimiento del acreedor invocado, sin que necesariamente se acuda expresamente a la exigencia de gravedad. En rigor en estos supuestos, a nuestro juicio, es la buena fe la que opera como límite a la procedencia de la excepción de contrato no cumplido en los casos en que ella es desechada o bien se deduce a contrario sensu en los casos en que es acogida. Esta solución nos resulta más coherente con la naturaleza y objetivos de esta institución. Revisaremos algunas hipótesis que nos parecen clarificadoras:

perseguida con el contrato, ante el actuar desprolijo y poco fidedigno de la actora en la confección del estudio. b) Corte de Apelaciones de Santiago. 11 de agosto de 2003. Rol No11527-2002. Gaceta Jurídica, No 278, 2003, pp. 141 y ss. Se demandó la terminación del contrato, cobro de rentas insolutas, multas e indemnizaciones basado en el incumplimiento contractual de su arrendataria. La parte demandada alegó no estar obligada a cumplir el contrato porque el inmueble arrendado no era apto para la finalidad o destino que se tuvo en vista al tiempo de la celebración. La Corte concluyó, en sus considerandos quinto y sexto, que al haber incumplido el arrendador su obligación de entregar la documentación necesaria para que el inmueble fuera apto para el fin a que ha sido arrendado, no podía exigir a su arrendatario el pago de las multas e indemnizaciones que reclama.

40 Corte de Apelaciones de La Serena. 19 de diciembre de 2011. Rol No 1203-2003. Disponible en http://vlex.com/vid/-366595062?ix_resultado $=1.0$ \&query\%5Bq $5 \mathrm{D}=366595062$ [Fecha de visita 23 de agosto de 2013], considerando No 7 . En este caso la resolución del contrato e indemnización de perjuicios se fundó en el incumplimiento de la obligación de prestar asesoría para asegurar la calidad técnica de las obras que se ejecutaban en terreno y que habían sido proyectadas por la universidad, proyecto relacionado con la instalación de un centro de cultivos de especies marinas en la localidad de Puerto Aldea, lo que acarreó una deficiente calidad técnica de las obras que se ejecutaban.

La demandada opuso primeramente la excepción de contrato no cumplido fundado en el no pago de parte del precio convenido.

En el juicio la actora no probó haber pagado íntegramente el precio convenido y se probó el cumplimiento imperfecto de la universidad demandada: no efectuar las inspecciones técnicas a que se había comprometido en la convención.

Cabe sí precisar que no obstante la vinculación de la excepción de contrato no cumplido con las exigencias de la resolución, la Corte hace descansar la procedencia de la excepción de contrato no cumplido en la proporcionalidad, así lo expresa en el considerando octavo. 


\subsection{1) La proporcionalidad del incumplimiento ${ }^{41}$}

La proporcionalidad de los incumplimientos concernidos refleja claramente la interposición de la excepción de contrato no cumplido de conformidad a la buena fe. Por esto, cada vez que se funde en un incumplimiento del acreedor que es desproporcionado, considerando el incumplimiento del deudor, la exceptio no debería prosperar.

En esta dirección nuestros tribunales han considerado adecuada la suspensión de la obligación de pagar parte del precio si el incumplimiento del deudor ha ocasionado perjuicios al acreedor, rechazándose la procedencia de la excepción de contrato no cumplido que este ha deducido. Así la Corte Suprema ha sostenido: "Que tampoco se acogerá la excepción de contrato no cumplido, fundado en el artículo 1552 del Código Civil, basado en el hecho de que la actora adeuda parte del precio convenido en la compraventa, porque la demanda de autos se basa en que las cosas vendidas no reunian las calidades que se habian convenido, lo que le ha supuesto perjuicios, por lo que parece perfectamente esperable que en esas circunstancias se haya suspendido el pago del saldo de precio. Cuando la demandante debió pagar el saldo de precio, la demandada ya habia incurrido en el incumplimiento que por este juicio se le reprocha. En estas circunstancias, el incumplimiento que la demandada denuncia en contra de la actora no aparece adecuado para enervar la acción indemnizatoria, menos aún cuando consta en autos que la demandada ha accionado judicialmente para el cobro de las facturas, a partir de la sentencia Rol 960-2008, del Primer Juzgado Civil de Talcahuano, acompañada en autos. Debe tenerse presente, en este sentido, que la excepción de incumplimiento contractual debe ser ejercida siempre de una manera proporcionada, calidad que la excepción de incumplimiento contractual opuesta por la demandada no reúne, desde el momento que la excepción que opone no es apropiada para oponerse a que este tribunal pueda valorar los perjuicios derivados de la entrega imperfecta de la cosa comprada. Distinto es que, después de determinada la indemnización en favor de la actora, se compensen total o parcialmente las respectivas obligaciones, en el caso que

41 Parte de la doctrina francesa considera que la proporcionalidad es una medida de apreciación del abuso del derecho, vinculado con la buena fe, y que determina que la excepción no puede aplicarse, Popineau-Dehaullon (2008), p. 96. Ghestin (2001), p. 43. Orlando, Marie-Astrid (2012). L'exception d'inexécution. Saarbrükcken: Éditions Universitaires Européenes, pp. 31-32. Pillebout (1971), pp. 208 y ss. En la doctrina italiana Persico acude también a este criterio como manifestación de un límite fundado en la buena fe objetiva, el autor, sí vincula la proporcionalidad con descartar la procedencia de la excepción en incumplimiento de poca entidad, Persico (1955), p. 141, pp.144-145.

Cruz considera que en la resolución y la excepción de contrato no cumplido la proporción tiene incidencia solo que es diferente. Así en materia de resolución la proporción es entre el incumplimiento de las partes y el grave efecto de la misma resolución. En la exceptio, la proporción dice relación la falta de cumplimiento del demandante. Cruz Moreno (2004), pp. 75-76. 
corresponda" 42 . No obstante, la claridad de la parte final de este considerando de la sentencia de la Corte Suprema, creemos que en este caso, a partir de los hechos asentados, confluyen dos criterios, el de proporcionalidad, ante la entrega de un producto defectuoso por parte del deudor no era proporcionado invocar para fundar la excepción de contrato no cumplido el incumplimiento del acreedor de pagar parte del precio; y ciertamente, uno de causalidad, el incumplimiento del actor fue consecuencia del incumplimiento de su deudor porque la suspensión de pago de parte del precio se debe al cumplimiento defectuoso del deudor.

Nos parece que el mismo criterio se sigue en el conocido caso Incomin S.A, con Enami S.A., donde la Corte Suprema se pronuncia respecto al requisito del incumplimiento en la excepción, no obstante, rechazarse por no haber sido opuesta oportunamente en juicio. En lo referido al incumplimiento, la Corte afirma que la excepción de contrato no cumplido no puede proceder ante el incumplimiento de obligaciones que en el ámbito de los compromisos asumidos por las partes tiene una significación jurídica menor, fundado ello en la buena fe, empleando la denominación de obligación principal. Si bien, hasta aquí, podría pensarse que se equipara el incumplimiento a la gravedad de la resolución, creemos que el tenor del considerando se debe a una transcripción de las opiniones de los profesores Fernando Fueyo y Jorge López Santa María, ya que más adelante, la Corte es más precisa al agregar: "Que, resumiendo lo razonado

42 Corte Suprema. 31 de octubre de 2012. Rol No 3325-20. “Zorin S.A. con Compañía Siderúrgica Huachipato S.A”. Disponible en http://www.legalpublishing3.cl/maf/app/docu mentVM? \&src=laley\&lr=i0ad6007a00000140e081fd0b6586249c\&docguid=i0ADFABB5 BA50E2F381BA517890B6891B\&hitguid=i0ADFABB5BA50E2F381BA517890B6891B\& epos $=1 \& \mathrm{td}=2 \& \mathrm{xao}=0 . \mathrm{i0ADFAB} 87 \mathrm{~B} 0 \mathrm{C} 8 \mathrm{D} 25381 \mathrm{~B} 0 \mathrm{D} 0 \mathrm{~F} 03 \mathrm{ED} 6 \mathrm{FB} 4 \mathrm{C} \&$ searchFrom $=$ \&save $\mathrm{d}$ Search=false \&crumb-action=append [fecha de visita 26 de agosto de 2013], considerando nro. 13 .

Se demandó indemnización de perjuicios fundado en el incumplimiento contractual de parte de la vendedora y que el demandante hace consistir en que la cosa entregada tenía unas características distintas a las que se había convenido, pues, mientras las 1.500 toneladas de rodillos de laminación en desuso debían contener una determinada composición química, particularmente de Níquel, resultó acreditado que la primera partida que se vendió a los Estados Unidos, por orden de la compradora, carecía de dicha composición.

El demandado opuso la excepción de contrato no cumplido, fundado en el cumplimiento parcial del acreedor, ya que le adeuda el pago de parte del precio.

El tribunal de primera instancia después de desestimar la excepción de contrato no cumplido, acogió la demanda, con costas y condenó a la demandada a pagar por concepto de daño emergente la suma de $\$ 243.673 .148$; por lucro cesante US $\$ 330.0000$ y a título de dańo moral \$500.000.000, más reajustes e intereses.

La parte demandada dedujo en contra de dicho fallo y su complemento, recursos de casación en la forma y apelación y, en segunda instancia formuló excepciones de prescripción y cosa juzgada. La Corte de Apelaciones de Santiago después de desestimar el arbitrio formal, decidió a) rechazar, con costas, las excepciones deducidas en esa instancia; b) revocar la sentencia de primer grado que condenó a la demandada a pagar a la actora $\$ 500.000 .000$ por dańo moral, y en su lugar desestima en esta parte la demanda y; c) confirmar en lo demás apelado. En contra de esta sentencia se dedujo recurso de casación en la forma y fondo. 
en las consideraciones precedentes -y al margen de la inoportunidad y consiguiente improcedencia de su formulación-la pretendida defensa de ENAMI, fundada en el incumplimiento parcial de "INCOMIN S.A." respecto de las obligaciones que, en el contexto global del contrato, presentan una envergadura menor, no constituia un motivo suficientemente serio que la excusase de satisfacer su compromiso principal y básico para la ejecución del contrato como era aquel de entregar a "INCOMIN S.A." la cantidad acordada de mineral en bruto para el procedimiento de lixiviación". De esta forma aun cuando se reconoce el incumplimiento en que incurrió Incomin S.A.: el haber devuelto productos con exceso de humedad y con menor cantidad de ley de cobre, haber incurrido en retrasos al devolver los productos y adeudar ciertas prestaciones a Enami S.A., a causa de la utilización de un cargador frontal de su propiedad; este no resulta proporcionado para que el deudor pueda oponer con éxito la excepción de contrato no cumplido, ya que con su ejercicio pretendió justificar la suspensión de la entrega de 30.000 toneladas mensuales de mineral a Incomin S.A. para su tratamiento ${ }^{43}$.

Es importante precisar que la proporcionalidad que debe existir para que opere la excepción de contrato no cumplido guarda estricta relación, en estos supuestos, con el incumplimiento del deudor y del demandante. Ciertamente no se trata de una proporcionalidad estricta o matemática, sino sí atendido a ese incumplimiento del demandante se encuentra justificado o no la negativa provisional del deudor al cumplimiento. Lo que se trata de evitar con el límite de la buena fe es el ejercicio abusivo del derecho, es decir, un ejercicio no razonable contrario a la actuación de una persona razonable y diligente ${ }^{44}$. En esta dirección nuestros tribunales

43 Corte Suprema. Rol No 1594-2001, considerandos cuadragésimo séptimo a cuadragésimo noveno.

En este juicio se demandó por Incomin S.A. para que se condenara a Enami S.A. al cumplimiento del contrato de maquila de minerales oxidados de cobre, pactado entre ambas $y$, en subsidio, en el caso de considerarse imposible el cumplimiento del contrato, para que se declarara la resolución del mismo, condenándose, en ambos eventos, a la demandada, a la indemnización de los perjuicios ocasionados. El tribunal de primera instancia acogió demanda subsidiaria interpuesta. Este fallo fue impugnado por actor y Tribunal de Alzada confirmó lo dictado en primera instancia. Interpuesto recurso de casación en la forma y fondo, se mencionó como infringido, entre otros, el artículo 1552. La Corte Suprema rechazó ambos.

En la instancia quedó acreditado que, en lo concerniente al cumplimiento de las obligaciones que le imponía el contrato de maquila, Enami no satisfizo aquella consistente en suministrar 30.000 toneladas mensuales de mineral para su tratamiento por parte de Incomin S.A.; y esta cumplió con su obligación de someter al procedimiento de lixiviación el material en bruto que le entregaba Enami, construyendo una planta para realizar ese tratamiento, pero incurrió, a su vez, en otra clase de incumplimientos de obligaciones reguladas en el contrato, al haber devuelto productos con exceso de humedad y con menor cantidad de ley de cobre, de acuerdo a la regulación estipulada sobre la materia; por haber incurrido en retrasos al devolver los productos; y por adeudar ciertas prestaciones a Enami, a causa de la utilización de un cargador frontal de propiedad de esta.

44 En términos más amplios, planteándolo como un criterio que opera siempre Cruz Moreno (2004), pp.75 y ss. 
han resuelto que "el incumplimiento de las obligaciones contractuales en que han incurrido los contratantes [...], resultan proporcionales, teniendo para ello, especialmente en consideración, que el precio acordado por las partes en relación a la obligación de la Universidad de efectuar la inspección en terreno, a fin de prestar asistencia técnica en los términos pactados en el contrato, ascendía a la suma de $\$ 4.980 .000$, mientras que el saldo del precio adeudado por la actora, no solucionado en la forma y tiempo convenido, alcanzaba a la cantidad de \$3.350.003. En consecuencia, no cabe sino concluir que el incumplimiento imperfecto de la obligación de prestar la asistencia técnica en terreno, imputado a la demandada, resulta racionalmente equivalente al incumplimiento de la obligación de pago integro del precio asumida por la actora, quien adeudaba una suma equivalente a casi un $70 \%$ del valor total estipulado por los contratantes" 45 .

\subsection{2) Causalidad del incumplimiento}

Para acoger o denegar la excepción de contrato no cumplido ha tenido también incidencia, en lo resuelto por nuestros tribunales, la relación causa-efecto que existe entre los posibles incumplimientos. Es por ello que la excepción se estima procedente si el incumplimiento del deudor es consecuencia del incumplimiento del acreedor; en caso contrario su ejercicio no debe prosperar ${ }^{46}$. Así ha acontecido, rechazándose la excepción de contrato no cumplido, si el no pago de los servicios prestados por parte del acreedor se debe al incumplimiento de la obligación de la deman-

Acoge como criterio, la razonabilidad según las circunstancias, para determinar la procedencia de la excepción de contrato no cumplido los principios de derecho europeo de los contratos (9:201).

Parte de la doctrina considera que es lo mismo que está detrás de la exigencia de proporcionalidad que efectúa la Corte de Casación francesa, Popineau-Dehaullon (2008), pp. 424-425.

45 Corte de Apelaciones de La Serena. Rol No 1203-2003. En la misma dirección, Corte de Apelaciones de La Serena. 31 de julio de 2012. Rol No 39-2012. "Inmobiliaria Constructora y Comercializadora Pirodais Limitada con Inversiones Serena S.A". Disponible en http://www.legalpublishing3.cl/maf/app/documentVM?\&src=laley\&lr=i0ad6007a0000014 0e0a24ee178249dd4\&docguid=i0ADFAB87B85C4B7B81B86495AACFC260 \&hitguid $=\mathrm{i}$ 0ADFAB87B85C4B7B81B86495AACFC260\&epos $=1 \& \mathrm{td}=3 \& \mathrm{ao}=0 . \mathrm{i} 0 \mathrm{ADFAB} 87 \mathrm{~B} 0 \mathrm{C} 8 \mathrm{D} 2$ 5381B0D0F03ED6FB4C\&searchFrom=\&savedSearch=false\&crumb-action=append [fecha de visita 26 de agosto de 2013].

46 En esta dirección Persico afirma, como otros criterios, el de la relación de sucesión de los incumplimientos y el de causalidad. Conforme al primero, cada parte puede justificar su propio incumplimiento solamente si le ha precedido el incumplimiento de la otra, no pudiendo oponer la excepción quien ha incumplido primero. Conforme al segundo, el incumplimiento del que alega la excepción debe estar motivado solo por el incumplimiento de la otra parte, no por otros fines como represalia o fines de lucro; plantea que debe producirse una dependencia causal respecto de los incumplimientos de los contratantes y en rigor, el incumplimiento de una de las partes debe constituir la causa única y terminante, la justificación jurídica del otro incumplimiento, Persico (1955), pp. 141-144. 
dada -deudor- (mantención y reparación de los neumáticos de la actora, que incluso ocasionó la muerte de un trabajador) ${ }^{47}$.

El mismo criterio ha sido empleado para acoger la excepción de contrato no cumplido. En esta dirección, la Corte de Apelaciones de Valdivia, luego de exigir que el incumplimiento sea de magnitud concluye que: "la causa de los perjuicios alegados y probados durante el transcurso del juicio es, precisamente, el incumplimiento contractual de la Constructora Alcus Limitada consistente en una construcción deficiente y no ajustada a lo convenido entre las partes.

Resulta, entonces, que el cumplimiento imperfecto de parte de la mencionada empresa es la causa tanto del incumplimiento del demandado principal legitimo, en virtud del articulo 1552, según lo expresado en el considerando anterior como de los perjuicios sufridos por el mismo" 48 .

47 Juzgado de Letras en lo Civil de Calama. 7 de septiembre de 2003. Rol No 35141. "Corporación Nacional del Cobre de Chile con Thor Servicios y Asesorías en Ahorro de Neumáticos Limitada". Disponible en http://www.legalpublishing3.cl/maf/app/documen tVM? \&src=laley\&lr=i0ad $8181500000140 \mathrm{e} 0$ beb7 ddbff1 ca7a\&docguid=i0ADFABE1B 1 C92E8781B10694A807BC35\&hitguid=i0ADFABE1B1C92E8781B10694A807BC35\& epos $=1 \& \mathrm{td}=1 \& \mathrm{ao}=0 . \mathrm{i} 0 \mathrm{ADFAB} 87 \mathrm{~B} 0 \mathrm{C} 8 \mathrm{D} 25381 \mathrm{~B} 0 \mathrm{D} 0 \mathrm{~F} 03 \mathrm{ED} 6 \mathrm{FB} 4 \mathrm{C} \&$ searchFrom $=\&$ saved Search=false\&crumb-action=append [fecha de visita 28 de agosto de 2013].

En este caso se demandó la indemnización de los perjuicios ocasionados por el incumplimiento del contrato de prestación de servicios de mantención integral y reparación de neumáticos para una división de Codelco. El demandado opuso a la pretensión indemnizatoria la excepción de contrato no cumplido. En rigor fundado en el artículo 1552, debió haber solicitado la compensación de la mora. Pronunciándose acerca de la excepción de contrato no cumplida opuesta, el tribunal sostuvo: "Que, la excepción de contrato no cumplido por parte de Thor Saan Ltda., no será oída, puesto que solo la puede alegar el contratante diligente, vale decir, el que ha cumplido o se allana a cumplir en forma y tiempo, de conformidad al articulo 1552 del Código Civil; y habiéndose determinado el incumplimiento del contrato por parte de la demandada, no se encuentra en posición de poder exigir a su contraparte el cumplimiento de las obligaciones establecidas en el contrato". A partir de los hechos probados se advierte que el incumplimiento de la actora, de pagar los servicios prestados encuentra su razón de ser en el incumplimiento del contrato por parte del deudor.

En la misma dirección, la Corte Suprema ha sostenido: "el incumplimiento del promitente comprador de su obligación de pagar la primera cuota del saldo del precio, permitió que los sentenciadores lleguen a la convicción que el actor no cumplió la obligación asumida y de esa manera, quedó impedido de atribuirle a su contraparte el incumplimiento de sus obligaciones, que sustenta en su acción". Corte Suprema. 10 de noviembre de 2010. Rol No 411-2009. "Ortiz Quiroz, Jorge B. con Sociedad Agrícola y Ganadera Pachingo Ltda". Disponible en http://vlex.com/vid/-333046398?ix_resultado=1.0\&query\%5Bq\%5D=Sociedad + Agr\%C3 $\% A D$ cola $+y+$ Ganadera+Pachingo+ [fecha de visita 28 de agosto de 2013].

48 Corte de Apelaciones de Valdivia. 14 de marzo de 2008. Rol No 676-2008. "Constructora Alcus Limitada contra Juan Carlos Araya Rivera”. Disponible en http://www.legalpublishing3.cl/maf/app/documentVM?\&src=laley\&lr=i0ad8181600000140e0c50a3adb3d9 d3b\&docguid=i977532942C97724A1FF8A29735DF7728\&hitguid $=$ i 977532942 C 9772 4A1FF8A29735DF7728\&epos $=1 \& \mathrm{td}=1 \&$ ao $=0 . \mathrm{i} 0$ ADFAB87B0C8D25381B0D0F03ED6 FB4C\&searchFrom=\&savedSearch=false\&crumb-action=append [fecha de consulta 28 de agosto de 2013], considerandos tercero y cuarto. Las partes celebraron un contrato de construcción de una casa habitación. Se probó la existencia de un saldo de precio insoluto y, por otra parte, que la Constructora cumplió en forma imperfecta las obligaciones emanadas del 
En similar sentido la Corte Suprema ha señalado: "que las facturas que se cobran fueron emitidas a contar del 30 de julio del año 2005, encontrándose la primera de ellas pagada parcialmente, siendo las restantes de fechas posteriores, constando en el proceso que, a partir de esa época, la demandada remitió correos electrónicos a la demandante informándole sobre la mala calidad del servicio de embalaje, con lo cual no cabe sino presumir que, al no cobrarse deudas anteriores a esa fecha, el demandado estaba cumpliendo y llano a cumplir con su parte en la obligación, la que fue incumplida exclusivamente por el actor al disminuir la calidad del servicio prestado, ocasionando reclamos de clientes a la demandada principal" ${ }^{49}$.

Lo mismo acontece en aquellos casos en que nuestros tribunales han estimado que ambos contratantes han incumplido, mas acoge la excepción de contrato no cumplido tras constatar que el incumplimiento del demandado se debe al incumplimiento del actor. Así la Corte Suprema ha acogido la excepción de contrato no cumplido, luego de acreditarse que el demandante reconvencional, "el propietario incumplió su obligación contractual tácita de posibilitar la normal ejecución de la obra encargada, toda vez que impidió el acceso a la propiedad al demandante-demandado reconvencional- $y$ a sus trabajadores, imposibilitando con ello el progreso de la misma"; y que por su parte, si bien este ejecutó obras en el inmueble del demandado -demandante reconvencional- tendientes a dar satisfacción a su compromiso principal de construir íntegramente dos edificaciones según las especificaciones generales de que da cuenta el contrato, lo cierto es que dicho cumplimiento debe estimarse imperfecto, toda vez que no

contrato celebrado, debido a que la casa construida presenta importantes deficiencias que requieren de reparación. La Corte consideró que no resultaba procedente que se rechace la demanda principal de cobro de saldo de precio y se acoja la demanda reconvencional de indemnización de perjuicios, teniéndose en cuenta que el cumplimiento imperfecto por parte del demandante principal de sus obligaciones contractuales es la causa del incumplimiento imperfecto de parte del demandado principal así como de los perjuicios que este ha sufrido, ya que se está considerando dos veces el mismo hecho, justificándose el incumplimiento del demandado principal y ordenando el pago de los perjuicios que alega.

49 Corte Suprema. Rol No 9540-2009. El demandante solicitó la condena de la demandada a pagar la suma de $\$ 79.262 .524$, por concepto del precio de los servicios de packing o embalaje de fruta y afines, consignado en las facturas que cobra, más reajustes e intereses corrientes, desde la fecha del vencimiento de cada una de ellas, con costas.

La demandada opuso la excepción de contrato no cumplido y demandó reconvencionalmente la restitución de $\$ 13.380 .896$, fundado en el embalaje defectuoso de la demandante. Entre las partes existió un contrato de prestación de servicios, no escriturado, en virtud del cual, el demandado entregaba frutas, principalmente limones, para que la demandante las embalara y etiquetara de acuerdo al mercado a que se destinaban. La relación comercial se inició el año 2001. La actora, en la temporada del año 2005, remitió al mercado japonés fruta de menor calidad, que debía ser destinada a Estados Unidos y realizó la clasificación de calibres y colores en forma manual, de noche y con deficiente iluminación, porque la máquina calibradora, que se usaba al efecto, estaba con desperfectos. La demandada en cuanto tomó conocimiento hizo formalmente los reclamos a la demandante. 
fue controvertido el hecho de que faltando catorce días para la llegada de la fecha en que las obras debían ser entregadas completamente terminadas, el avance de las mismas indicaba la imposibilidad absoluta de cumplir con ello, pues el primer edificio se encontraba en tres cuartas partes terminado y el segundo solamente exhibía el emparejamiento del terreno y la cimentación de las fundaciones, situación por la que estos sentenciadores estiman, existió también incumplimiento contractual de su parte ${ }^{50}$.

\subsection{3) El incumplimiento y la conducta del deudor que lo acepta}

Existen ciertas hipótesis en las cuales, no obstante haberse verificado el incumplimiento del acreedor, que podría haberse invocado para fundar la excepción de contrato no cumplido, la exceptio no prosperará porque el deudor ha desplegado una conducta, que en los hechos, lo avala, tolera y acepta. Por esto la buena fe objetiva se presentará como un límite a la procedencia de la excepción. En el fondo, el incumplimiento del acreedor se funda en hechos conocidos por el deudor, que ha avalado con su propia conducta, restándole con ello entidad al incumplimiento mismo ${ }^{51}$. Este criterio se encuentra íntimamente ligado con la conducta que ha desplegado el deudor. Si él acepta en los hechos un incumplimiento de su acreedor no puede pretender, con posterioridad desconociendo su conducta y/o manifestación de voluntad, fundar en ellos la procedencia de la excepción, ya que estaría actuando de forma contraria a las exigencias de la buena fe objetiva.

En este sentido se ha desechado la excepción de contrato no cumplido, si los deudores pretenden amparar el no pago de las rentas de un local porque no se les entregó de forma adecuada, ya que este carecía de patente comercial de club nocturno. Los sentenciadores sostuvieron que los deudores "no exigieron la terminación de ese arriendo ni tampoco

50 Corte Suprema. 9 de marzo de 2009. Rol No 6859-2007. “Gabriel Adán Hernández Pastén con Wilson Fernando Rodríguez Cabrera”. Disponible en http://www.legalpublishing3.cl/ $\mathrm{maf} / \mathrm{app} /$ documentVM? \&src=laley\&lr=i0ad8181600000140e0d3e56cda5fe076\&docguid=i0 ADFABE1B11CBBC881B12FAE17F3AD8A\&hitguid=i0ADFABE1B11CBBC881B12FAE1 7F3AD8A\&epos=1\&td=1\&ao=o.i0ADFAB87B0C8D25381B0D0F03ED6FB4C\&searchFro $\mathrm{m}=\&$ savedSearch=false\&crumb-action=append [fecha de consulta 29 de agosto de 2013] .

Se demandó la resolución de un contrato de ejecución de obras e indemnización de perjuicios, fundado en los incumplimientos del demandado: modificación unilateral del contrato solicitando mayores obras, no pago de las obras, e imposibilitar el acceso al lugar de trabajo. El demandado opone la excepción de pago y demanda reconvencionalmente la resolución del contrato e indemnización de perjuicios fundado en la no ejecución de la obra por parte del contratista de conformidad a los términos pactados. El demandado reconvencional niega los hechos y opone la excepción de contrato no cumplido.

51 En la doctrina italiana Bigliazzi es de la opinión contraria a la aplicación de este criterio en los casos de cumplimiento tardío, ya que la mera tolerancia no puede considerarse una prórroga del plazo o una modificación de los términos originarios del contrato. BigLiAzzi (1988), pp. 24-25. 
reclamaron una eventual reducción de la renta pactada, significa que han estado obligados a pagarlas sin que puedan argüir como justificación para su negativa el hecho que ahora esgrimen, contrariando de esa forma su propia conducta anterior ${ }^{52}$ ". De forma similar, en otro caso, nuestros tribunales han considerado que la ausencia de permiso de edificación y recepción final no es un incumplimiento que justifica la procedencia de la excepción, ya que "no se advierte como este hecho le impide al arrendatario usar el inmueble para el destino que fue arrendado, el que se encuentra estipulado en la cláusula segunda del contrato que señala: "La propiedad en galpón y patio se utilizará exclusivamente a bodegaje y a oficina administrativa y habitacional de cuidador las piezas interiores de ésta", en especial si se tiene presente que el contrato se celebró el 3 de julio de 2003 y las rentas impagas se refieren a los

52 Corte Suprema. 30 de mayo de 2012. Rol No 416-2012. Disponible en http://vlex.com/ vid/-378403714?ix_resultado=1.0\&query\%5Bq\%5D=378403714 [fecha de visita 2 de septiembre de 2013]. Se demandó la terminación del contrato de arrendamiento por falta de pago de rentas. Los demandados adujeron que no estaban en mora de cumplir con su obligación de pagar las rentas toda vez que, por su lado, la actora ha incumplido su obligación de entregarle el local arrendado en forma adecuada, esto es, no le ha entregado ni mantiene vigente la patente de club nocturno para el local arrendado, condición esencial del contrato, circunstancia que le ha impedido montar espectáculos en ese recinto. Ha omitido, por ende, los trámites que permitan la recepción definitiva, por parte de la I. Municipalidad respectiva, para habilitar ese local como discoteque con capacidad para más de 500 personas y, en fin, no le hace llegar oportunamente las facturas para el pago de las rentas.

En juicio se probó que al tiempo de la suscripción del contrato, por decreto alcaldicio, no se había renovado la patente de club nocturno. La Corte Suprema, luego de determinar la regla contractual que rigió a las partes, concluye que el carácter de condición esencial, asignado en la cláusula tercera a la vigencia de la patente aludida, solo puede asumirse como alusivo a un hecho que, en su caso, facultaba a los arrendatarios para instar por la terminación inmediata del contrato, del modo precisamente previsto en su cláusula decimoquinta. En efecto, una interpretación distinta haría inexplicable y carente de todo sentido que, a pesar de carecer de tal permiso municipal, esos arrendatarios hayan perseverado en el contrato por un lapso que, cuando menos, se prolongó por más de tres años. Vale decir, que no obstante ello lo hayan ejecutado o cumplido durante ese tiempo, sin protestas previas.

En otro caso similar, un voto de minoría se pronunció en la misma dirección. En efecto el sentenciador consideró: "Si bien es cierto el acreedor-arrendador-faltó a su obligación de entregar la patente habilitada para operar como bar restaurante, el caso es que si entregó el inmueble de que se trataba y, más aún, el demandado lo recibió y lo explotó; primero como bar restaurante precisamente y luego al menos como restaurante, sin expendio de alcohol. La excepción de contrato no cumplido no puede extenderse al punto que permita a un contratante usar de la cosa arrendada y sin embargo no pagar rentas, porque ese arrendatario tuvo a su mano las acciones para reclamar el cumplimiento de lo debido o para resolver el contrato y siempre para resarcir sus perjuicios. Si en lugar de entablarlas prefirió explotar el negocio en otra forma, fue él mismo quien varió por su voluntad el giro, dejando en calidad de superflua la obligación no cumplida por su contraria". Corte de Apelaciones de Rancagua. 1 de junio de 2010. Rol: 10082009. Disponible en http://www.legalpublishing3.cl/maf/app/documentVM?\&src=laley\& $\mathrm{l} r=\mathrm{i} 0 \mathrm{ad} 8181500000140 \mathrm{e} 5 \mathrm{a} 0 \mathrm{f6441}$ e69a5b7\&docguid=i8F4F159CD1E206D0B159013E8 CC0BB40\&hitguid =i8F4F159CD1E206D0B159013E8CC0BB40\&epos $=1 \& \mathrm{td}=1 \&$ ao $=0$. i0ADFAB87B0C8D25381B0D0F03ED6FB4C\&searchFrom=\&savedSearch=false \&crumb -action=append [fecha de visita 2 de septiembre de 2013], primer fundamento del voto de minoría. 
arriendos desde junio de 2006, tiempo suficiente para solicitar con anterioridad la regularización que ahora, luego de tres años, se aduce para terminar el contrato" 53 .

En todos estos casos si bien ha existido un incumplimiento al tenor de lo pactado por las partes, ha sido la propia aplicación práctica del contrato que han hecho lo que ha modificado el contenido y alcance del mismo, operando una verdadera interpretación auténtica de él, al tenor del artículo 1564 inciso $3^{\circ}$ del CC. Por lo anterior, no es posible que prosperare la excepción de contrato no cumplido fundado en esta clase de incumplimiento, si ambas partes toleraron que el contrato continuara ejecutándose de una forma distinta de lo pactado. Aceptar su procedencia implicaría claramente un ejercicio abusivo por parte del deudor.

Consideramos que este mismo ejercicio abusivo se presentaría en aquellas hipótesis en las que se acepta sin reparos la prestación ejecutada por el deudor (acreedor de la obligación recíproca) y luego pretende el deudor correlativo fundar la excepción de contrato no cumplido en un incumplimiento que, no obstante no coincidir con la regla contractual pactada, fue tolerado y aceptado. En esta dirección la Corte Suprema ha sostenido: "que el cumplimiento de la actora fuera de los plazos pactados devino del cambio en las especificaciones técnicas adoptado por la demanda$d a$, quien no solo se abstuvo de representar ese retraso, sino que acordó con aquélla un encargo adicional a lo originalmente pactado y que ya se venía ejecutando de manera imperfecta. Este proceder de la demandada que el fallo cuestionado tiene por demostrado en autos, llevó a decidir que la litigante en mención no está en condiciones de resistirse a la ejecución de sus compromisos,

53 Corte Suprema. 1 de junio de 2010. Rol No 7762-2008. “José Rufino Espinoza González con Hernán Torrejón Gallardo”. Disponible en http://www.legalpublishing3.cl/maf/app/do cumentVM? \&src=laley\&lr=i0ad8181500000140e5a37359eb7db8cb\&docguid=i0ADFABE 1B1C92E8781B106ECB687D171\&hitguid=i0ADFABE1B1C92E8781B106ECB687D17 1 \&epos $=1 \& \mathrm{td}=1 \&$ ao $=$ o.i0ADFAB87B0C8D25381B0D0F03ED6FB4C\&searchFrom $=$ \&sa vedSearch=false $\&$ crumb-action=append [fecha de visita 2 de septiembre de 2013], considerando segundo y tercero de la sentencia de reemplazo.

Las partes celebraron un contrato de arrendamiento de una propiedad, un galpón y patio, que se utilizaría exclusivamente a bodegaje y a oficina administrativa y habitacional de cuidador en las piezas interiores de esta. Se demandó la terminación del contrato por no pago de las rentas e indemnización de perjuicios. El demandado opuso la excepción de contrato no cumplido y demandó reconvencionalmente la terminación del contrato fundado en que el demandante se ha negado a entregar el certificado de recepción final, razón por la que no desea mantener el arriendo atendida la imposibilidad de usar la propiedad para la actividad que la arrendó.

La Corte Suprema, en sentencia de reemplazo, rechazó la procedencia de la excepción si el incumplimiento se funda en la imposibilidad de emplear la propiedad para los fines que se arrendó por ausencia de certificado de recepción final, ya que se acreditó que la propiedad sí era usada y que habían transcurrido más de 3 años desde la celebración del contrato, previos al incumplimiento del deudor. 
fundada en incumplimientos de la contraria que, en su momento, no le resultaron de gravedad"54.

Tras el análisis de los casos resueltos por nuestra jurisprudencia, que se hacen cargo de examinar el incumplimiento como requisito para que proceda la excepción de contrato no cumplido, destacamos todas aquellas sentencias que nos permiten afirmar que ella procede frente a cualquier incumplimiento mientras su ejercicio no sea contrario a la buena fe. De esta forma entendemos que hay un grupo de incumplimientos que revisten una gravedad suficiente para que pueda prosperar tanto la acción resolutoria como la excepción de contrato no cumplido, pudiendo el acreedor en definitiva optar ${ }^{55}$. Sin embargo, no vemos aquí el terreno propio de la excepción sino en todos aquellos incumplimientos que acontezcan mientas no vulneren la buena fe, es decir, si el incumplimiento del acreedor en el que se funda la excepción es desproporcionado, o es consecuencia directa del incumplimiento del propio deudor, o bien este con su conducta le ha restado entidad porque ha avalado la ejecución del contrato en términos distintos de lo pactado. Nos parece que de esta forma se concilian claramente los requisitos, fundamentos y efectos de esta institución.

\section{3) La PRUeba de la EXCEPCión de CONTRATO NO CUMPLIDO}

Hemos precisado que uno de los requisitos de la excepción de contrato no cumplido es que el acreedor no haya cumplido con su prestación ni se encuentre llano a hacerlo. Del mismo modo, que ella no es un requisito o presupuesto de la pretensión de cumplimiento ni de la resolución, de manera que el acreedor no es quien tendrá que probar que ha cumplido o está llano a hacerlo per se para que pueda prosperar su acción $^{56}$. Sin embargo, en la práctica esto último es requerido por la aplica-

54 Corte Suprema. 27 de agosto de 2013. Rol No 7635-2012. "Industrias Lahsen Limitada con Constructora Puerto Iquique S.A.”. Disponible en http://www.legalpublishing3.cl/maf/ app/documentVM? \&src=laley \&lr=i0ad6007900000140ea31f5fe5e34657 d \& docguid=i7F00 0001C021241E81C046EFD67AFA91 \&hitguid=i7F000001C021241E81C046EFD67AFA $91 \&$ epos $=1 \& \mathrm{td}=3 \& \mathrm{xo}=0$. i0ADFAB87B0C8D25381B0D0F03ED6FB4C\&searchFrom $=$ \&s avedSearch=false $\&$ crumb-action=append [fecha de visita 3 de septiembre de 2013].

55 En las hipótesis de incumplimiento resolutorio situamos los incumplimientos dolosos (determinan la pérdida de confianza del acreedor), es decir, procedería la excepción por la entidad del incumplimiento. En la doctrina italiana, en la misma dirección BigLiazzi (1988), pp. 23, 35 y ss. En la doctrina francesa, se indica que el comportamiento de quien invoca la excepción debe ser considerado y debe ella negarse si el comportamiento de quien la opone hace imposible el cumplimiento de la otra parte, situación que nos parece equivale a un incumplimiento doloso, Ghestin (2001), p. 41.

56 Con una opinión contraria Masnatta considera que si la carga de la prueba de la excepción correspondiera al demandado, esta actuaría como una especie de actio doli, lo que no comparte. El excipiens solo debe oponer la excepción para hacer recaer la prueba sobre el actor. En definitiva la carga del propio cumplimiento o del previo cumplimiento de la contra- 
ción que nuestros tribunales hacen de los artículos 1552 y 1698 del CC. En este sentido la Corte de Apelaciones de Valparaíso ha resuelto que: " $n i$ el vendedor ni el comprador se encontraban a la data en que dedujeron sus respectivas demandas de resolución y cumplimiento de contrato, en situación de solicitar con éxito estas declaraciones del tribunal, como tampoco podia pretenderse el pago de cantidad alguna como indemnización de perjuicios sufridos, atendido a que ninguno de los dos contratantes probó haber cumplido o estar llano a cumplir con sus obligaciones, en los términos que exige el artículo 1.552 del Código Civil, lo que lleva a estos sentenciadores a revocar la sentencia en alzada, en cuanto acoge la demanda principal, declarando la resolución del contrato y condenando al demandado a la restitución del abono del precio pagado por el comprador ${ }^{57}$.

En términos generales en esta materia, estimamos que es el deudor quien deberá probar el fundamento fáctico de su excepción, ya que él se está oponiendo a la pretensión de cumplimiento del acreedor. Conforme al tenor del artículo 1698 del CC., el acreedor que demanda la ejecución forzada de la obligación deberá probar la existencia de la obligación y alegará el incumplimiento del deudor. En su defensa el deudor afirmará que ha incumplido pero que su incumplimiento está amparado en la excepción de contrato no cumplido, debiendo probar su sustrato fáctico, los hechos en que se funda su negativa de cumplir ${ }^{58}$.

parte, compete al demandante. Reconoce sí que la situación cambia en los cumplimientos defectuosos, ya que en este caso las pruebas de las objeciones recae sobre el demandado. Masnatta, Héctor (1967). Excepción de incumplimiento contractual. Buenos Aires: AbeledoPerrot, pp. 101-104.

57 Corte de Apelaciones de Valparaíso. 4 de julio de 2005. Rol No3615-2003. "Marcelo Ernesto Saavedra de la Paz con Fabián Ramírez Pijoan”. Disponible en http://www.legalpublishing3.cl/maf/app/documentVM? \&src=laley\&lr=i0ad81816000001410364234466b 153b6\&docguid=i0ADFAB87B68DBC7681B696AE5386EE87 \&hitguid=i0ADFAB87B 68DBC7681 B696AE5386EE87\&epos $=1 \& \mathrm{td}=4 \& \mathrm{ao}=\mathrm{o} . \mathrm{i0ADFAB} 87 \mathrm{~B} 0 \mathrm{C} 8 \mathrm{D} 25381 \mathrm{~B} 0 \mathrm{D} 0 \mathrm{~F}$ 03ED6FB4C\&searchFrom=\&savedSearch=false\&crumb-action=append [fecha de visita 9 de septiembre de 2013]. En este caso, el demandado no opuso la excepción de contrato no cumplido, mas el tribunal considera a partir del artículo 1552 que es un requisito de estas acciones que el acreedor pruebe que ha cumplido o se encuentra llano a hacerlo. La Corte Suprema, conociendo del recurso de casación deducido en contra de esta sentencia reitera el considerando reproducido.

58 En esta dirección Emilio Rioseco afirma: “Tanto el derecho del acreedor formulado por vía de acción, como el derecho del deudor, ejercitado a través de demanda reconvencional o por vía de excepción (non adimpleti contractus), se sustentan en elementos de hechos que son constitutivos específicos en los dos primeros casos e impeditivos en el último, hechos cuya prueba corresponde a quien los invoca en su propio interés", y agrega, más adelante, "cuando el deudor haya opuesto la excepción del artículo 1552 y en base a esta haya probado -porque puede también ocurrir que malogre su prueba- el hecho impeditivo en que sustenta su excepción: el incumplimiento por parte del acreedor de la contraprestación que tiene o la negativa de este último a cumplir. Solo entonces surge para el acreedor la carga probatoria opuesta, que consiste en el hecho extintivo: haber cumplido por su parte la contraprestación o estar dispuesto a cumplirla”. Rioseco Enríquez, Emilio (1984): "El onus probandi en 
Parte de la doctrina ha criticado que la carga de la prueba de la excepción de contrato no cumplido corresponda al deudor porque se le impondría la carga de probar un hecho negativo, es decir, que el acreedor no ha cumplido o que no estuvo llano a hacerlo ${ }^{59}$. Sin embargo, en rigor ello no será así, porque el deudor alegará y probará la existencia o subsistencia de la obligación del acreedor, dependiendo si estamos ante un incumplimiento total o ante un cumplimiento defectuoso, y será este quien deberá probar que ha cumplido ${ }^{60}$. En definitiva, la prueba del acreedor del cumplimiento o que se encuentra llano a cumplir, solo se justificará jurídicamente en la medida que el deudor haya opuesto la excepción de contrato no cumplido.

Así por ejemplo, pensemos en la modalidad más típica de incumplimiento, la de cumplimiento defectuoso del acreedor, y el deudor opone la exceptio rite non adimpleti contractus. Optamos por esta forma de incumplimiento, aquella en la que se despliega una actividad tendiente al cumplimiento mas no se logra ejecutar la prestación en los términos en que fue pactada, porque usualmente el acreedor que ejerce la pretensión

la excepción del contrato incumplido". Revista de Derecho Universidad de Concepción. Nro. 176 , p. 109.

59 A propósito de la prueba de la excepción, y luego de referirse a la postura del profesor Rioseco, Bruno Caprile indica "Desde luego, la decisión que se adopte tiene enorme importancia en el juicio y la doctrina del profesor Rioseco Enríquez no está exenta de dificultades para el demandado, pues le impone la carga de demostrar un hecho negativo, como es el incumplimiento de la obligación del demandante o que no está llano a cumplir", CAPrILE (2013), p. 60. Con una opinión contraria, Daniel Peñailillo concluye, tras efectuar una serie de distingos de las negaciones - hechos negativos-, que ellas son generalmente susceptibles de prueba por el hecho positivo contrario, según corresponda de acuerdo a la distribución de la carga de la prueba. Peñailillo, Daniel (1984). La prueba en materia sustantiva. Concepción: Departamento de Derecho Privado, Universidad de Concepción, pp.117-120.

En este sentido el profesor Abeliuk afirma que es al deudor que se excepciona a quien corresponde la prueba, "Creemos que el problema se resuelve por la mera aplicación de las reglas generales en la materias, derivadas del Art.1698. Corresponde probar la obligación al que la alega; luego el deudor que se excepciona con la adimpleti contractus debe acreditar que por parte de su acreedor hay una obligación derivada de un contrato bilateral. Establecido esto, el acreedor queda forzado a probar su propio cumplimiento, que es la extinción de dicha obligación”. Abeliuk (2010), pp.945-946.

Consideramos en definitiva, en la misma línea a Messineo quien afirma "no recae sobre el demandante excepcionante la carga de la prueba del incumplimiento; sino que, frente a la excepción del demandado, incumbe al acreedor la prueba del cumplimiento.

En otras palabras, la posición de las partes debe imaginarse como sigue: una de ellas, demanda en juicio porque (según la afirmación del actor) no ha cumplido, opone que no lo ha hecho porque el actor a su vez tampoco ha cumplido; corresponde al actor aportar la prueba de su cumplimiento si quiere constreñir al demandado a cumplir”. Messineo, Francesco (1952). Doctrina General del Contrato. Traducción de R.O Fontanarrosa, S. Sentis y M. Voleterra. Buenos Aires: Ediciones Jurídicas Europa-América, pp. 435-436. Siguiendo a este Melich Orsini sostiene que la carga de la prueba del incumplimiento del acreedor corresponde al deudor, lo que resulta más evidente en los casos de cumplimiento parcial o inexacto. Cfr. Mélich-Orsini, José (1997). Doctrina General del Contrato. Caracas: Editorial Jurídica Venezolana, pp. 791-792. 
de cumplimiento ha realizado, al menos, un principio de ejecución de su propia prestación. En estos casos el deudor probará el incumplimiento del acreedor, el hecho que impide el presupuesto de la demanda del actor (acreedor), en definitiva la subsistencia de la obligación, ya que en el incumplimiento de esa obligación está fundando su negativa de cumplir. Confirmando lo anterior, nuestra Corte Suprema a resuelto que "sobre la demandada pesaba la carga procesal de acreditar que los equipos y el sistema comprado a la actora no sirvió a los fines inherentes a su instalación y puesta en marcha; circunstancia que resultó justificada para los jueces de la instancia, según quedó determinado en la quinta consideración del fallo del Tribunal de Alzada de Antofagasta; de modo tal que no queda sino concluir que la actora cumplió imperfecta y parcialmente con la obligación primordial de entregar lo vendido, cuya utilidad quedó en entredicho, puesto que, tratándose de un sistema satelital de control para frecuencia y ruta, era preciso contar con los códigos asignados a los aparatos que conforman el sistema instalado, los que, en definitiva, resultaron estar comandados por Elecon Sud América Limitada, con quien debió negociar la empresa de buses demandada a objeto de reactivar su funcionamiento" 61 . En el mismo orden de ideas, nuestra Corte Suprema ha sostenido que "atendido que el inciso $1^{\circ} \mathrm{del}$ artículo 1698 del Código Civil impone la carga de probar la extinción de la obligación a quien alega esta circunstancia y que la demanda de cobro de la obligación correlativa supone que el acreedor afirma haber cumplido aquélla de que él es deudor, la alegación de contrato no cumplido sitúa a quien ejerce la acción en posición de probar que dio completo y oportuno cumplimiento a las obligaciones que a su parte imponia el contrato bilateral' 62 . En similar dirección la Corte de Apelaciones de San Miguel ha sostenido que: "es del caso señalar que la prueba de la excepción de contrato no cumplido corres-

61 Corte Suprema. 10 de mayo de 2010. Rol No 7360-2008. "Sysexel Computación Limitada contra Transporte Público de Pasajeros Línea 29”. Disponible en http://www.legalpublishing3.cl/maf/app/documentVM? \&src=laley\&lr=i0ad6007900000140ea6c5be866114a5d\& docguid=iDDEC1C8737949C21EEC7E40EF819CEF1\&hitguid=iDDEC1C8737949C2 $1 \mathrm{EEC} 7 \mathrm{E} 40 \mathrm{EF} 819 \mathrm{CEF} 1 \&$ epos $=1 \& \mathrm{td}=1 \& \mathrm{ao}=\mathrm{o} . \mathrm{i} 0 \mathrm{ADFAB} 87 \mathrm{~B} 0 \mathrm{C} 8 \mathrm{D} 25381 \mathrm{~B} 0 \mathrm{D} 0 \mathrm{~F} 03 \mathrm{ED} 6$ FB4C\&searchFrom=\&savedSearch=false\&crumb-action=append [fecha de visita 3 de septiembre de 2013], considerando decimotercero. En este caso se había demandado el cumplimiento del contrato: pago de parte del precio de los servicios e indemnización de perjuicios. El demandado opuso excepción de contrato no cumplido fundado en que los equipos entregados no eran de propiedad de la actora.

En primera instancia no se dio lugar a la demanda por aplicación del artículo 1552. Resolución que se confirmó en apelación. En contra de esta sentencia se dedujo recurso de casación en la forma y en el fondo.

62 Corte Suprema. 1 de enero de 2007. Rol No 4856-2004. "Hormigones Premix Ltda. con Empresa Constructora Ibáñez Ltda”. Disponible en http://www.legalpublishing3.cl/maf/ app/documentVM? \&src=laley\&lr=i0ad6007a00000140ea48952fa684c3a0\&docguid=i0AD FABE1B1C92E8781B106A949DB933D\&hitguid=i0ADFABE1B1C92E8781B106A949D B933D\&epos $=1 \& \mathrm{td}=6 \& \mathrm{xao}=0$. i0ADFAB87B0C8D25381B0D0F03ED6FB4C\&searchFro $\mathrm{m}=\&$ savedSearch=false\&crumb-action=append [fecha de visita 3 de septiembre de 2013]. 
pondía efectuarla a quien la alegó, es decir, a la demandada, y no lo hizo. A mayor abundamiento, debemos mencionar que el contrato suscrito entre las partes señala en su cláusula segunda que "la arrendataria declara recibir en buen estado de conservación y a su entera satisfacción la propiedad (...)", lo cual, sumado a la falta de prueba de los incumplimientos que atribuye al actor, hacía imposible que el tribunal a quo acogiera la excepción deducida"63.

Si el incumplimiento ha sido total el deudor también deberá probar los hechos en que se funda la excepción: la existencia de un crédito. En concreto sí acontecerá en este evento que, alegada la excepción, al demandado le bastará con la prueba que haya rendido el demandante porque su crédito nace del mismo contrato que este ha probado y, conforme al artículo 1698 del CC., es precisamente al acreedor a quien le ha correspondido la prueba de la existencia de la obligación. Se advierte, por tanto, que no existe alteración de lo dispuesto por el artículo 1698 del Código civil ${ }^{64}$.

Conforme a lo expuesto, no creemos que al acreedor deba exigírsele y, por ende, que deba probar a priori, para que prospere la ejecución forzada o la resolución demandada, que ha cumplido o que se encuentra llano a hacerlo, porque este no es un requisito de procedencia de estos remedios. Cosa distinta es que a esa demanda el deudor oponga la excepción de contrato no cumplido porque, luego de que el deudor pruebe los hechos en que se funda su excepción, tendrá el acreedor que probar que ha cumplido o que ha estado llano a hacerlo para que pueda prosperar su acción.

\section{CONCLUSIONES}

Tras el análisis que hemos realizado pasamos a exponer nuestras conclusiones:

1. La exigibilidad de las obligaciones emanadas de un contrato bilateral depende de que la obligación sea pura o simple o bien que sujeta a alguna modalidad esta se haya verificado.

63 Corte de Apelaciones de San Miguel. Rol No 486-2012.

64 Rodríguez-Rosado afirma que no es una alteración de la carga de la prueba de las excepciones sino que el hecho constitutivo de la excepción será al mismo tiempo el de la demanda, y por tanto, alegada la excepción, será el demandante el encargado de probar los hechos extintivos de esta. Rodríguez-Rosado (2013), p. 86.

Refiriéndose a la carga de la prueba en el mismo sentido en la doctrina española, véase Cruz Moreno (2004), pp.170 y ss. Espín, en esta dirección, reconoce que en los casos de cumplimiento defectuoso la prueba recae sobre el demandado, dependiendo de ello las posibilidades de éxito de la excepción. En los casos de incumplimiento total, afirma que al demandado le bastará con alegar la excepción de contrato no cumplido para hacer caer la carga de la prueba en el actor, ya que este al reclamar la prestación tendrá que suministrar la prueba del contrato que los liga. Espín (1964), p. 580. 
La simultaneidad, fundamento de la excepción de contrato no cumplido, no afecta la exigibilidad de las obligaciones sinalagmáticas, no incidiendo en los requisitos de procedencia de la misma. Situados en sus efectos y en su vinculación con otros remedios del acreedor, creemos que basta con cumplir con el requisito que es propio, según si estamos ante la ejecución forzada o la resolución y en ninguno de estos mecanismos de tutela es presupuesto que el acreedor pruebe que ha cumplido o que se encuentre llano a hacerlo.

2. Es posible afirmar la procedencia de una excepción de contrato no cumplido, en los casos de incumplimiento anticipado, con alcance general. Si bien solo encontramos normas que lo prevén tratándose del contrato de compraventa, en el Código civil y en la Convención de Viena sobre compraventa internacional de mercaderías, en los demás casos estamos ante un vacío o laguna legal. Para colmarlo importa el fundamento de la institución, los principios de buena fe y equidad y el recurso de la analogía -considerando las hipótesis especialmente regladas-. Conforme a lo anterior afirmamos que la falta de exigibilidad de la obligación de una de las partes cede ante la pérdida de confianza de que la prestación podrá ser ejecutada, pudiendo oponerse con éxito la excepción de contrato no cumplido.

3. La gravedad del incumplimiento no es un requisito de procedencia de la excepción de contrato no cumplido ni de cualquier modalidad de esta -exceptio non rite adimpleti contractus o aquella que procede ante incumplimientos anticipados-. Erradamente la doctrina y la jurisprudencia nacional han traspasado esta exigencia por la equiparación que se hace con otro efecto particular de los contratos bilaterales: la resolución. Sin perjuicio de lo anterior, todo incumplimiento que es resolutorio, es decir, que reúne gravedad suficiente, permite al acreedor optar entre la resolución u oponer la excepción de contrato no cumplido, mas la existencia de un terreno común no priva de un campo de aplicación más amplio a la exceptio.

4. Una interpretación armónica con la naturaleza, fundamento y finalidad de la excepción de contrato no cumplido nos lleva a afirmar que en materia de incumplimiento, basta cualquiera mientras no sea su ejercicio contrario a la buena fe.

Tras analizar los casos resueltos por nuestros tribunales ello acontece si el incumplimiento del acreedor, en el que se funda la excepción, es desproporcionado, o es consecuencia directa del incumplimiento del propio deudor, o bien este con su conducta le ha restado entidad porque ha avalado la ejecución del contrato en términos distintos de lo pactado.

5. No es requisito para que prospere una pretensión de cumplimiento forzado o de resolución que el acreedor pruebe que ha cumplido o 
que se encuentra llano a hacerlo. Cosa distinta es que a esa demanda el deudor oponga la excepción de contrato no cumplido, en ese evento él deberá probar los hechos en que funda su excepción y tendrá el acreedor, a su vez, que probar que ha cumplido o que ha estado llano a hacerlo para que pueda prosperar su acción. Esta interpretación guarda una clara armonía con el tenor de los artículos 1552 y 1698 del Código civil.

\section{BIBLIOGRAFÍA CITADA}

- Abeliuk, René (2010). Las obligaciones. Tomo II. 5a Edición. Santiago: Editorial Jurídica de Chile.

- Alcalde Silva, Jaime (2011). "El tratamiento de los incumplimientos recíprocos en el derecho chileno". En Carvajal, Patricio; Miglietta, Massimo (a cura di): Estudios Juridicos en homenaje al profesor Alejandro Guzmán Brito. Milán: Edizioni dell'Orso, pp.37-86.

- Alessandri, Arturo; Somarriva, Manuel y Vodanovic, Antonio (2004). Tratado de las obligaciones. 2a ed. Santiago: Editorial Jurídica de Chile. Vol. 1.

- Atiyah, P.S; Smith, Stephen (2005). Atiyah's Introduction to the law of contract. 6a Edition. New York: Clarendon Press Oxford University.

- Baraona, Jorge (2008). "Algunas consideraciones sobre el retraso en el cumplimiento de las obligaciones: su configuración y eficacia”. En Pizarro, Carlos (coordinador): Estudios de Derecho civil V. Santiago; Editorial LegalPublishing, pp. 370 y ss.

- Bennett, Trevor (1987). “art. 71”. En Bianca-Bonell: Commentary on the International Sales Law. Milan: Giuffrè, pp. 513-524.

- Bianca, C.M (1992). "Eccezione d'inadempimento e buona fede". En Il contratto. Silloge in onore di G. Oppo. Padova,

- Bigliazzi, Lina (1988). "Risoluzione per inadempimento". En Galgano, Francesco (a cura di): Commentario del Codice civile Scialoja-Branca. Bologna: Nicola Zanichelli Editore, pp. 1-85.

- Calvo Caravaca, Alfonso-Luis (1998). "Comentario al art. 71". En Díez-Picazo, Luis (director): La compraventa internacional de mercaderias. Madrid: Editorial Civitas S.A., pp.560-568.

- Caprile Biermann, Bruno (2012). "Algunos problemas ofrecidos por la excepción de contrato no cumplido y, en especial, el de su invocación para atajar la acción resolutoria en el caso de incumplimiento recíproco de los contratantes”. Revista de Derecho de la Pontificia Universidad Católica de Valparaíso. Nro. 
39. Disponible en http://www.scielo.cl/scielo.php?pid=S071868512012000200002\&script=sci_arttext [fecha de visita 19 de agosto de 2013].

- Carbonnier, Jean (2004). Droit Civil. Paris: Presse Universitaires de France.

- Carrasco Perera, Ángel (2010). Derecho de Contratos. Madrid: Ed. Thomson Reuters.

- Cassin, René (1914). De l'exception tirée de l'inexécution dans les rapports synallagmatiques: exception non adimpleti contractus. Paris: Librairie de la Société du Recueil Sirey

- Claro Solar, Luis (1978). Derecho civil chileno y comparado, Tomo $X:$ De las Obligaciones. Santiago: Editorial Jurídica de Chile.

- Cruz Moreno, María (2004). La Exceptio non Adimpleti contractus. Madrid: Tirant lo Blanch.

- De la Prida, Manuel (2012). La excepción de contrato no cumplido: Fundamento y naturaleza jurídica. Tesis para optar al grado de Licenciado en Ciencias Jurídicas. Valparaíso, 117 pp.

- Enneccerus, Ludwig (1953).Tratado de derecho civil. Traducción de Blas Pérez González y José Alguer. 2a edición. Tomo II. Barcelona: Bosch.

- Espín Cánovas, Diego (1964). "La excepción de incumplimiento contractual". Anuario de Derecho civil (Madrid), Nro. 17, vol. 2, pp.543-581.

- Fernández Urzainqui, Francisco (1997). "La regla de la simultaneidad en el cumplimiento de las obligaciones bilaterales". Revista Crítica de Derecho Inmobiliario, Nro. 639, pp. 403-462.

- Fueyo Laneri, Fernando (2004). Cumplimiento e incumplimiento de las obligaciones. $3^{\text {a }}$ ed. Santiago: Editorial Jurídica de Chile.

- Galván Bernabeu, José Antonio (1998). "Conferencia Inaugural del II Congreso Chileno de Derecho Privado". Revista de Derecho de la Universidad Católica de Valparaíso, vol. XIX, pp.13-20.

- Ghestin, Jacques (2001). “Exception d'Inexécution”. En Fontaine, Marcel; Viney, Geneviève (coordinadores): Les sanctions de l'inexécution des obligations contractuelles. Bruselas: L.G.D.J.

- Honnold, John (1999). Uniform Law for International Sales under the 1980 United Nations Convention. $3^{\mathrm{a}}$ ed. Holanda: Kluwer Law International.

- Larenz, Karl (1958). Derecho de obligaciones. Traducción de José Santos Briz. Tomo II. Madrid: Revista de Derecho Privado.

- López Santa María, Jorge (2010). Los contratos: Parte General. 5a edición. Santiago: Editorial Jurídica de Chile.

- Malecki, Catherine (1999). L'exception d'inexécution. Paris: L.G.D.J. 
- Masnatta, Héctor (1967). Excepción de incumplimiento contractual. Buenos Aires: AbeledoPerrot.

- Mejías Alonzo, Claudia (2013). "La excepción de contrato no cumplido y su consagración en el Código civil chileno". Revista Chilena de Derecho, vol. 40 No 2, pp. 389-412.

- Mejías Alonzo, Claudia (2011). El incumplimiento resolutorio en el Código civil. Santiago: LegalPublishing.

- Mejí́as Alonzo, Claudia (2008). "El incumplimiento contractual y sus modalidades", en Guzmán Brito, Alejandro (editor): Estudios de Derecho civil III. Santiago: Editorial LegalPublishing, pp. 459-478.

- Orlando, Marie-Astrid (2012). L'exception d'inexécution. Saarbrükcken: Éditions Universitaires Européenes.

- Persico, Giovanni (1955). Eccezione d'inadempimento. Milano: Giuffré.

- Pinna, Andrea (2003). "L'exception pour risque d'inexécution". Revue trimestrielle de droit civil, pp. 33 y ss.

- Peñailillo, Daniel (1984). La prueba en materia sustantiva. Concepción: Departamento de Derecho Privado, Universidad de Concepción.

- Pizarro Wilson, Carlos (2011). "La excepción por incumplimiento contractual en el derecho civil chileno". En Varas Braun, Juan Andrés; Turner Saelzer, Susan y otros (coordinadores): Estudios de Derecho Civil. Jornadas nacionales de derecho civil 2005-2009. Tomo II, Santiago: AbeledoPerrot, pp. 181 y ss.

- Pillebout, Jean-Francois (1971). Recherches sur l'exception d'inexécution. Paris, L.G.D.J.

- Popineau-Dehaullon, Catherine (2008). Les remèdes de justice privée à l'inexécution du contrat étude comparative. Paris: L.G.D.J.

- Realmonte, Francesco (1965). Voz "Eccezione di inadempimento". Enciclopedia del Diritto, vol XV, pp. 222-239.

- Rioseco Enríquez, Emilio (1984): “El onus probandi en la excepción del contrato incumplido". Revista de Derecho Universidad de Concepción. Nro. 176, pp. 107-110.

- Rodríguez Grez, Pablo (2004). "Sobre la excepción del contrato no cumplido". Revista Actualidad Jurídica, No 9, pp. 123 y ss.

- Rodríguez-Rosado, Bruno (2013). Resolución y sinalagma contractual. Madrid: Editorial Marcial Pons.

- Squella, Agustín (2011). Introducción al Derecho. 2a Edición. Santiago: Editorial Jurídica de Chile,

- Terrazas, Juan David (2004). "Algunas consideraciones sobre los principios generales del derecho y un breve análisis de su aplicación en el ordenamiento jurídico chileno". Revista de Derecho Universidad Católica del Norte. Año 11 No 1, pp. 133-159. 
- Treitel, Guenter (2004). An outline of the law of contract. 6a Edition. New York: Clarendon Press Oxford University.

- Vidal Olivares, Álvaro (2007). "Cumplimiento e incumplimiento contractual en el Código civil. Una perspectiva más realista”. Revista Chilena de Derecho. Nro. 34, Vol.1, pp. 41-59.

- Whittaker, Simon (2001). "Les sanctions de l'inexécution des contrats droit anglais". En Fontaine, Marcel; Viney, Geneviève (coordinadores): Les sanctions de l'inexécution des obligations contractuelles. Bruselas: L.G.D.J.

- Ziegel, Jacob (1981). "Report to the Uniform Law Conference of Canada on Convention on Contracts for the International Sale of Goods". Disponible en: http://www.cisg.law.pace.edu/cisg/text/ ziegel71.html [fecha de visita 19 de agosto de 2013].

- Ziegel, Jacob (1984). "The Remedial Provisions in the Vienna Sales Convention: Some Common Law Perspectives”. En Bender, Matthew: International Sales: The United Nations Convention on Contracts for the International Sale of Goods. New York: Galston \& Smit ed., pp. 9-43.

- Zweigert, Konrad; Kötz, Heim (1998). Introduction to comparative law, 2a Edition. New York: Clarendon Press Oxford University.

\section{JURISPRUDENCIA CITADA}

\section{a) Jurisprudencia judicial}

- Corte de Apelaciones de San Miguel. 22 de mayo de 1997. Rol No 1042. "Luisa Brousset con Santiago Aravena". Disponible en http://www.legalpublishing3.cl/maf/app/documentVM?\&src=laley\& lr $=\mathrm{i} 0$ ad6007a00000140ccc148a070a51fc7 \&docguid=i0ADFABE1B 2E4374181B2E8716D6AEFFA\&hitguid=i0ADFABE1B2E437418 1B2E8716D6AEFFA\&epos $=1 \& \mathrm{td}=1 \&$ ao $=0$. i0ADFAB87B0C8D 25 381B0D0F03ED6FB4C\&searchFrom=\&savedSearch=false\&crumbaction=append [fecha de visita 20 de agosto de 2013].

- Corte de Apelaciones de Santiago. 11 de septiembre de 2001. Rol No 3589-1999. "Inmobiliaria Esarvic S.A. con Inv. Torre Alameda S.A.”. Disponible en http://vlex.com/vid/inmobiliariaesarvic-s-torre-alameda 32113240?ix_resultado=1.0\&query $\% 5 \mathrm{~Bq} \% 5$ $\mathrm{D}=$ Inmobiliaria+Esarvic+ [fecha de visita 19 de agosto de 2013].

- Corte Suprema. 31 de marzo de 2003. Rol No1594-2001. "Incomin S.A. con Enami". Disponible en http://vlex.com/ vid/incomin-enami-32032899? ix_resultado $=1.0$ \&query\%5Bq\% $5 \mathrm{D}=32032899$ [fecha de visita 20 de agosto de 2013]. 
- Corte de Apelaciones de Santiago. 11 de agosto de 2003. Rol No11527-2002. Gaceta Juridica, No 278, 2003, pp. 141 y ss.

- Juzgado de Letras en lo Civil de Calama. 7 de septiembre de 2003. Rol No 35141. "Corporación Nacional del Cobre de Chile con Thor Servicios y Asesorías en Ahorro de Neumáticos Limitada”. Disponible en http:/www.legalpublishing3.cl/maf/app/documentV M? \&src=laley \&lr=i0ad8181500000140e0beb7ddbff1 ca7a\&docguid =i0ADFABE1B1C92E8781B10694A807BC35\&hitguid=i0ADFAB E1B1C92E8781B10694A807BC35\&epos=1 \& td = 1 \&ao=o.i0ADFA B87B0C8D25381B0D0F03ED6FB4C\&searchFrom=\&savedSearch =false \&crumb-action=append [fecha de visita 28 de agosto de 2013].

- Corte de Apelaciones de Valparaíso. 4 de julio de 2005. Rol No3615-2003. "Marcelo Ernesto Saavedra de la Paz con Fabián Ramírez Pijoan". Disponible en http://www.legalpublishing3.cl/ maf/app/documentVM? \&src=laley\&lr=i0ad81816000001410364 234466b153b6\&docguid=i0ADFAB87B68DBC7681 B696AE538 6EE87\&hitguid=i0ADFAB87B68DBC7681B696AE5386EE87\& epos $=1 \& \mathrm{td}=4 \&$ ao $=$ o.i0ADFAB87B0C8D25381B0D0F03ED6FB4C \&searchFrom=\&savedSearch=false\&crumb-action=append [fecha de visita 09 de septiembre de 2013].

- Corte Suprema. 1 de enero de 2007. Rol No 4856-2004. "Hormigones Premix Ltda. con Empresa Constructora Ibáñez Ltda". Disponible en http://www.legalpublishing3.cl/maf/app/documentV M? \&src=laley\&lr=i0ad6007a00000140ea48952fa684c3a0\&docguid =i0ADFABE1B1C92E8781B106A949DB933D\&hitguid=i0ADFA BE1B1C92E8781B106A949DB933D\&epos $=1 \& \mathrm{td}=6 \&$ ao $=0 . \mathrm{i0AD}$ FAB87B0C8D25381B0D0F03ED6FB4C\&searchFrom=\&savedSea rch=false\&crumb-action=append [fecha de visita 3 de septiembre de 2013].

- Corte de Apelaciones de Puerto Montt. 4 de diciembre de 2007. Rol No 240-2006. "Schoenahuer Kent Lloyd con Souther Chile Expeditions S.A. y otro". Disponible en: http://vlex.com/vid/332882654 ? ix_resultado $=1.0 \&$ query $\% 5 \mathrm{~Bq} \% 5 \mathrm{D}=$ Southern $+\mathrm{Chile}+\mathrm{E}$ xpeditions+S.A [fecha de visita 20 de agosto de 2013].

- Corte de Apelaciones de Arica. 29 de octubre de 2007. Rol No 311-2007. "Clotilde Crispin Quispe con Ilustre Municipalidad de Arica”. Disponible en: http://www.legalpublishing3.cl/maf/app/docu mentVM? \&src=laley \&lr=i0ad8181500000140e0329df698215e49\& docguid=i0ADFABE1B1C92E8781B106BD16F2AA7B\&hitguid=i0 ADFABE1B1C92E8781B106BD16F2AA7B\&epos=1 \& td= 1\&ao=o. i0ADFAB87B0C8D25381B0D0F03ED6FB4C\&searchFrom=\&sav edSearch=false \&crumb-action=append [fecha de visita 23 de agosto de 2013]. 
- Corte de Apelaciones de Valdivia. 14 de marzo de 2008. Rol No 676-2008. "Constructora Alcus Limitada contra Juan Carlos Araya Rivera”. Disponible en http://www.legalpublishing3.cl/maf/app/doc umentVM? \&src=laley \&lr=i0ad8181600000140e0c50a3adb3d9d3b \&docguid=i977532942C97724A1FF8A29735DF7728\&hitguid=i9 77532942C97724A1 FF8A29735DF7728\&epos=1\&td=1\&ao=o.i0A DFAB87B0C8D25381B0D0F03ED6FB4C\&searchFrom=\&savedSe arch=false $\&$ crumb-action=append [fecha de consulta 28 de agosto de 2013].

- Corte de Apelaciones de Copiapó. 12 de mayo de 2008. Rol No 8-2008. "Inmob. Xcaret Ltda. Con Inmob. Einers. Ramón Sánchez y Cía. Ltda.”. Disponible en http://vlex.com/vid/inmob-xcaretiners-ramon-sanchez 38318190?ix_resultado=1.0\&query $\% 5 \mathrm{~Bq} \%$ $5 \mathrm{D}=38318190$ [fecha de visita 19 de agosto de 2013].

- Corte de Apelaciones de Santiago. 6 de agosto de 2008. Rol No2008-2004. "Dahm Oyarzún, Jorge con Fuentes Belmar, Juan". Disponible en: http://www.legalpublishing3.cl/maf/app/documentV M? \&src=laley\&lr=i0ad8181600000140e03506b38967d2a5\&docgu $\mathrm{id}=\mathrm{i} 1 \mathrm{AF} 679 \mathrm{CBD} 2 \mathrm{~A} 7 \mathrm{~F} 7247754 \mathrm{~F} 2 \mathrm{DC6D} 29 \mathrm{D} 96 \mathrm{~B}$ \&hitguid=i1AF67 9CBD2A7F7247754F2DC6D29D96B\&epos $=1 \& \mathrm{td}=1 \&$ ao $=0 . \mathrm{i0AD}$ FAB87B0C8D25381B0D0F03ED6FB4C\&searchFrom=\&savedSea $\mathrm{rch}=$ false $\&$ crumb-action=append [fecha de visita 9 de septiembre de 2013].

- Corte Suprema. 9 de marzo de 2009. Rol No 6859-2007. "Gabriel Adán Hernández Pastén con Wilson Fernando Rodríguez Cabrera”. Disponible en http://www.legalpublishing3.cl/maf/app/documentV M? \&src=laley\&lr=i0ad8181600000140e0d3e56cda5fe076\&docguid =i0ADFABE1B11CBBC881B12FAE17F3AD8A\&hitguid=i0ADFA BE1B11CBBC881B12FAE17F3AD8A\&epos $=1 \& \mathrm{td}=1 \& \mathrm{ao}=0 . \mathrm{i0AD}$ FAB87B0C8D25381B0D0F03ED6FB4C\&searchFrom=\&savedSea $\mathrm{rch}=$ false $\&$ crumb-action=append [fecha de consulta 29 de agosto de 2013].

- Corte Suprema. 29 de septiembre de 2009. Rol No 2763-2003. Disponible en http://vlex.com/vid/-333768310?ix_resultado=1.0\&q uery\%5Bq\%5D=333768310 [fecha de visita 20 de agosto de 2013].

- Corte Suprema. 10 de mayo de 2010. Rol No 7360-2008. "Sysexel Computación Limitada contra Transporte Público de Pasajeros Línea 29". Disponible en http://www.legalpublishing3.cl/maf/app/docume ntVM? \&src=laley\&lr=i0ad6007900000140ea6c5be866114a5d\&doc guid=iDDEC1C8737949C21EEC7E40EF819CEF1 \&hitguid=iDD EC1C8737949C21EEC7E40EF819CEF1 \&epos $=1 \& \mathrm{td}=1 \& \mathrm{xa}=0 . \mathrm{i} 0$ ADFAB87B0C8D25381B0D0F03ED6FB4C\&searchFrom=\&saved 
Search=false\&crumb-action=append [fecha de visita 3 de septiembre de 2013].

- Corte Suprema. 1 de junio de 2010. Rol No 7762-2008. "José Rufino Espinoza González con Hernán Torrejón Gallardo”. Disponible en http://www.legalpublishing3.cl/maf/app/documentV M?\&src=laley\&lr=i0ad8181500000140e5a37359eb7db8cb\&docgui $\mathrm{d}=\mathrm{i} 0$ ADFABE1B1C92E8781B106ECB687D171\&hitguid=i0ADFA BE1B1C92E8781B106ECB687D171\&epos $=1 \& \mathrm{td}=1 \& \mathrm{ao}=0 . \mathrm{i} 0 \mathrm{ADF}$ AB87B0C8D25381B0D0F03ED6FB4C\&searchFrom =\&savedSear $\mathrm{ch}=$ false\&crumb-action=append [fecha de visita 2 de septiembre de 2013].

- Corte de Apelaciones de Rancagua. 1 de junio de 2010. Rol: 1008-2009. Disponible en http://www.legalpublishing3.cl/maf/ app/documentVM? \&src=laley\&lr=i0ad $8181500000140 \mathrm{e} 5 \mathrm{a} 0 \mathrm{f} 64$ 41e69a5b7\&docguid =i8F4F159CD1E206D0B 159013E8CC0B B 40\&hitguid $=i 8$ F4F159CD1E206D0B 159013E8CC0BB 40\& epos $=1 \& \mathrm{td}=1 \&$ ao $=$ o.i0ADFAB87B0C8D25381B0D0F03ED6FB4C \&searchFrom $=\&$ savedSearch=false\&crumb-action=append [fecha de visita 2 de septiembre de 2013].

- Corte Suprema. 10 de noviembre de 2010. Rol No 411-2009. "Ortiz Quiroz, Jorge B. con Sociedad Agrícola y Ganadera Pachingo Ltda”. Disponible en http://vlex.com/vid/-333046398?ix_resultado= $1.0 \&$ query $\% 5 \mathrm{~Bq} \% 5 \mathrm{D}=$ Sociedad + Agr $\% \mathrm{C} 3 \% \mathrm{AD}$ cola $+\mathrm{y}+$ Ganadera $+\mathrm{P}$ achingo+ [fecha de visita 28 de agosto de 2013].

- Corte Suprema. 24 de marzo de 2011. Rol No 3789-2009. "Fuentes Rodríguez, José Belisario con Canteras Lonco S.A." Disponible en: http://www.legalpublishing3.cl/maf/app/documentV M? \&src=laley \&lr=i0ad8181500000140e03bbf571f7680d3\&docgui $\mathrm{d}=\mathrm{i} 0066249 \mathrm{D} 187 \mathrm{~B} 4 \mathrm{~B} 95 \mathrm{DE} 55 \mathrm{C} 2 \mathrm{D} 8 \mathrm{~A} 8 \mathrm{C} 02667$ \&hitguid $=\mathrm{i} 006624$ 9D187B4B95DE55C2D8A8C02667\&epos $=1 \& \mathrm{td}=1 \& \mathrm{ao}=0 . \mathrm{i} 0 \mathrm{ADF}$ AB87B0C8D25381B0D0F03ED6FB4C\&searchFrom=\&savedSearc $\mathrm{h}=$ false\&crumb-action=append, considerando No 14 [fecha de visita 23 de agosto de 2013].

- Corte de Apelaciones de Concepción. 20 de junio de 2011. Rol No 64-2011. Disponible en: http://vlex.com/vid/-287419723?ix_re sultado $=1.0 \&$ query $\% 5 \mathrm{~Bq} \% 5 \mathrm{D}=287419723$ [fecha de visita 20 de agosto de 2013].

- Corte Suprema. 26 de julio de 2011. Rol No 9540-2009. "Exportadora de Frutas del Sur S.A. c. Servicios Integrales de Transporte S.A.". Disponible en http://www.legalpublishing3.cl/ $\mathrm{maf} / \mathrm{app} /$ documentVM? \&src=laley\&lr=i0ad8181600000140c167 8efbb28174e0 \&docguid=i86AEABF32D7E16A1A66F4F94CD03 DAF 1 \&hitguid=i86AEABF32D7E16A1A66F4F94CD03DAF1\& 
epos $=1 \& \mathrm{td}=1 \&$ ao $=$ o.i0ADFAB87B0C8D25381B0D0F03ED6FB4C \&searchFrom=\&savedSearch=false \&crumb-action=append [fecha de visita 19 de agosto de 2013].

- Corte de Apelaciones de La Serena. 19 de diciembre de 2011. Rol No 1203-2003. Disponible en http://vlex.com/vid/366595062?ix_resultado=1.0\&query\%5Bq\%5D=366595062 [Fecha de visita 23 de agosto de 2013].

- Corte Suprema. 7 de marzo de 2012. Rol No 3946-2011. "Irina Buvinic Gonella con Complejo Turístico Marbella S.A.” Disponible en http://www.legalpublishing3.cl/maf/app/documentVM?\&src=lale y\&lr=i0ad60079000001408916d145b1 14dfd8\&docguid=i0ADFAB 87B571733981B5732BBE34E200\&hitguid=i0ADFAB87B5717339 81B5732BBE34E200\&epos $=1 \& \mathrm{td}=1 \&$ ao $=0 . \mathrm{i} 0$ ADFAB87B0C8D25 381B0D0F03ED6FB4C\&searchFrom=\&savedSearch=false\&crumbaction=append [fecha de visita 16 de agosto de 2013].

- Corte Suprema. 25 de mayo de 2012. Rol No 12046-2011. "Eduardo Esteban Maraldi Olivo con Inmobiliaria Cores S.A.". Disponible en http://www.legalpublishing3.cl/maf/app/documentV M? \&src=laley\&lr=i0ad60079000001409757db991d 14e033\&docgu $\mathrm{id}=\mathrm{i} 0$ ADFAB87B706F0A881B71582079AF8F3\&hitguid=i0ADFAB 87B706F0A881B71582079AF8F3\&epos $=1 \& \mathrm{td}=1 \&$ ao $=0.10 A D F A B$ 87B0C8D25381B0D0F03ED6FB4C\&searchFrom =\&savedSearch=f alse\&crumb-action=append [fecha de visita 19 de agosto de 2007],

- Corte Suprema. 30 de mayo de 2012. Rol No 416-2012. Disponible en http://vlex.com/vid/-378403714?ix_resultado $=1.0 \&$ query $\% 5 \mathrm{~Bq} \% 5 \mathrm{D}=378403714$ [fecha de visita 2 de septiembre de 2013].

- Corte de Apelaciones de la Serena. 31 de julio de 2012. Rol No 39-2012. "Inmobiliaria Constructora y Comercializadora Pirodais Limitada con Inversiones Serena S.A.”. Disponible en http://www. legalpublishing3.cl/maf/app/documentVM? \&src=laley\&lr=i0ad60 07a00000140e0a24ee178249dd4\&docguid=i0ADFAB87B85C4B 7B81B86495AACFC260\&hitguid $=$ i0ADFAB87B85C4B7B81B8 $6495 \mathrm{AACFC} 260 \&$ epos $=1 \& \mathrm{td}=3 \&$ ao $=0 . \mathrm{i0ADFAB} 87 \mathrm{~B} 0 \mathrm{C} 8 \mathrm{D} 2538$ 1B0D0F03ED6FB4C\&searchFrom = \&savedSearch =false\&crumbaction=append [fecha de visita 26 de agosto de 2013].

- Corte de Apelaciones de San Miguel. 7 de septiembre de 2012. Rol No 486-2012. "Moyano Sepúlveda Kathia Pamela con González Pereira Eduardo Gastón”. Disponible en http://vlex.com/vid/400957010?ix_resultado=1.0\&query\%5Bq\%5D=400957010 [fecha de visita 20 de agosto de 2013].

- Corte Suprema 31 de octubre de 2012. Rol No 3325-20. "Zorin S.A. con Compañía Siderúrgica Huachipato S.A.” Disponible en 
http://www.legalpublishing3.cl/maf/app/documentVM?\&src=laley\& lr=i0ad6007a00000140e081 fd0b6586249c\&docguid=i0ADFABB5 BA50E2F381BA517890B6891B\&hitguid=i0ADFABB5BA50E2F3 81BA517890B $6891 \mathrm{~B} \&$ epos $=1 \& \mathrm{td}=2 \& \mathrm{ao}=0 . \mathrm{i0ADFAB} 87 \mathrm{~B} 0 \mathrm{C} 8 \mathrm{D} 25$ 381B0D0F03ED6FB4C\&searchFrom $=$ \&savedSearch=false\&crumbaction=append [fecha de visita 26 de agosto de 2013].

- Corte Suprema. 23 de mayo de 2013. Rol No 2152-2013. "Hernández Muñoz, Mauricio Eulogio con Scotiabank Chile". Disponible en: http://vlex.com/vid/hernandez-mua-mauricioscotiabank-chile-438375858?ix_resultado $=1.0 \&$ query $\% 5 \mathrm{~Bq} \%$ $5 \mathrm{D}=438375858$ [fecha de visita 23 de agosto de 2013].

- Corte Suprema. 27 de agosto de 2013. Rol No 7635-2012. "Industrias Lahsen Limitada con Constructora Puerto Iquique S.A.”. Disponible en http://www.legalpublishing3.cl/maf/app/documentV M?\&src=laley\&lr=i0ad6007900000140ea31f5fe5e34657d\&docguid $=\mathrm{i} 7 \mathrm{~F} 000001 \mathrm{C} 021241 \mathrm{E} 81 \mathrm{C} 046 \mathrm{EFD} 67 \mathrm{AFA} 91 \&$ hitguid $=\mathrm{i} 7 \mathrm{~F} 000001$ C021241E81C046EFD67AFA91 $\&$ epos $=1 \& \mathrm{td}=3 \& \mathrm{ao}=\mathrm{o} . \mathrm{i} 0 \mathrm{ADFAB} 8$ 7B0C8D25381B0D0F03ED6FB4C\&searchFrom=\&savedSearch=fal se\&crumb-action=append [fecha de visita 3 de septiembre de 2013].

\section{B) Jurisprudencia arbitral}

- Sentencia arbitral. 2 de enero de 2007. Rol No 622. Disponible en: http://www.camsantiago.com/sentencias/IndiceGral_2011/622. pdf [fecha de visita 23 de agosto de 2013].

- Sentencia arbitral. 20 de junio de 2001. Rol No 2012. Disponible en: http://www.camsantiago.com/sentencias/ IndiceGral_2011/212-01.pdf [fecha de visita 20 de agosto de 2013].

- Sentencia arbitral. 29 de diciembre de 2009. Rol No 11442009. Disponible en: http://www.camsantiago.com/sentencias/ IndiceGral_2011/1144\%20Bascu\%C3\%B 1\%C3\%A 1 n \% 20 Vald\%C3\%A9s.pdf [fecha de visita 20 de agosto de 2013]. 